\title{
Mg-rich ferric illite in marine transgressive and highstand systems tracts: Examples from the Paleoproterozoic Semri Group, central India
}

\author{
S. Banerjee ${ }^{a}$, S. Jeevankumar ${ }^{a}$ and P.G. Eriksson ${ }^{b}$ \\ ${ }^{a}$ Department of Earth Sciences, IIT Bombay, Powai, Mumbai 400076, India \\ ${ }^{b}$ Department of Geology, University of Pretoria, Pretoria 0002, South Africa
}

\section{Abstract}

This paper focusses upon two glauconitic sandstones in the Paleoproterozoic Deoland Formation and Chorhat Sandstone, both belonging to the Semri Group, central India. In both the cases glauconitic minerals occur in sandstones deposited in the marine realm, within a transgressive systems tract (TST) for the former unit and within a highstand systems tract (HST) for the latter. The proportion of glauconitic minerals increases in the paleo-offshore direction. Petrography reveals selective early glauconitization of detrital K-feldspars along their fringes, cleavages and the fractures created by volume expansion during progressive alteration, leading to the generation of peloids with small relics of the precursors. XRD and mineral chemistry reveal a structure typical of glauconite, and more akin to Mg-rich ferric illite. The mineral chemistry of the glauconitic mineral phases remains the same whether the glauconitization process was incipient or at an advanced stage.

These findings contrast with the previously held belief that ferric illite is confined to terrestrial or marginal marine sediments, and concurs with recent observations that the mineral can form in the open sea, but with high $\mathrm{Mg}$. Since there are no ferro-magnesian minerals in association with these Vindhyan glauconitic sandstones, the seawater appears 
to be the only source for the $\mathrm{Mg}$ and Fe required. The general low rate of sedimentation on Proterozoic open shelves would have permitted ferric illite formation even within a HST, as represented by the Chorhat Sandstone.

\section{Article Outline}

1. Introduction

2. Geological background

3. Laboratory methodologies

4. Studied formations and mode of occurrence of glauconitic minerals

4.1. Deoland formation

4.2. Chorhat sandstone

5. Petrography and XRD study of glauconitic rocks

6. Mineral chemistry of the 'glauconitic minerals' and their structures

7. Origin of the 'glauconitic minerals' in the Semri group

8. Paleogeographic and stratigraphic implications of 'glauconitic minerals' from the semri group

9. Conclusions

Acknowledgements

References

\section{Introduction}

Glauconitic minerals, considered as the most sensible indicators of low sedimentation rates, although common on modern continental shelves, are poorly known from Mesoproterozoic or older rocks ([Odin and Matter, 1981], [Amorosi, 1997] and [Lee et al., 2002]). This paper describes glauconitic minerals, more akin to Mg-rich ferric illite from the Paleoproterozoic Semri Group of the Vindhyan Supergroup (Fig. 1A) and enriches the poor record of known glauconitic occurrences in the Precambrian. Odin and Matter (1981) considered that 'glauconitic minerals' form a continuous series between glauconitic smectite $\left(\mathrm{K}_{2} \mathrm{O}\right.$ ranging from 3 to $\left.5 \%\right)$ and glauconitic mica $\left(\mathrm{K}_{2} \mathrm{O}\right.$ up to $\left.10 \%\right)$. Progressive incorporation of potassium is seen by them as converting the former 
'immature' variety into the latter 'mature' variety of glauconites; the colour of the mineral becomes darker green as this occurs. These authors, however, recorded a compositional gap in terms of $\mathrm{Fe}_{2} \mathrm{O}_{3}$ (total) between ferric illite and 'true' glauconites at higher $\mathrm{K}_{2} \mathrm{O}$ content, $\mathrm{Fe}_{2} \mathrm{O}_{3}$ (total) not exceeding $10 \%$ in the immature variety and not less than $15 \%$ in the mature examples. Subsequent workers, nevertheless, found a compositional continuum between glauconite and ferric illite and included the latter in the glauconitic minerals family ([Dasgupta et al., 1990] and [Deb and Fukuoka, 1998]; see also [Berg-Madsen, 1983] and [Ireland et al., 1983]). This paper subscribes to the later viewpoint because the green minerals in the Semri Group are similar to glauconitic minerals structurally and in terms of their $\mathrm{K}_{2} \mathrm{O}$ content, even though they were incipiently developed. The paper, therefore, does not discriminate between glauconitic smectite, glauconitic mica and ferric illite when using the term glauconitization in referring to the mineralization process.
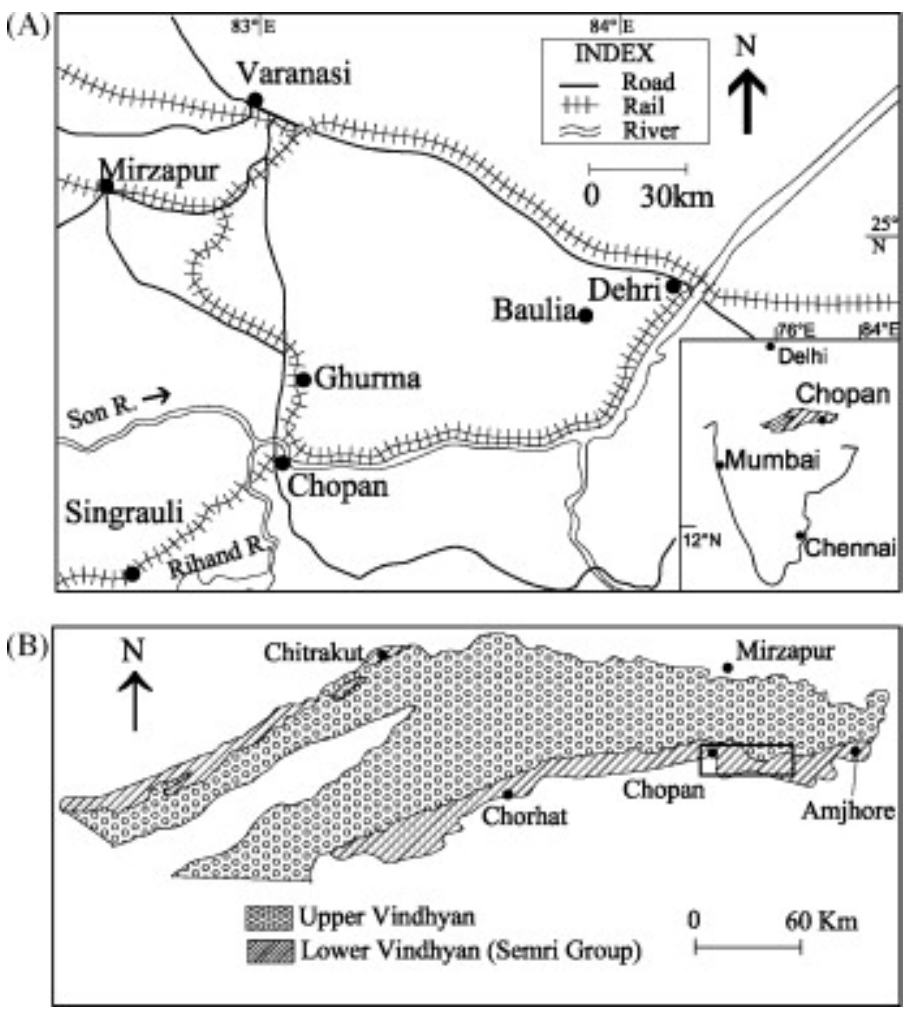

Fig. 1. Location of the study area (inset map of India shows Vindhyan outcrops in the Son valley) (A). Geological map showing outcrops of the Vindhyan Supergroup in the 
Son valley (after, Auden, 1933) with study area around Chopan marked by rectangular block (B).

Glauconite is common in sedimentary deposits on marine shelves, while ferric illite substitutes for it in terrestrial paleoenvironments ([Odin and Matter, 1981], [Amorosi, 1997] and [Baker, 1997]) or under hypersaline conditions (Kossovskaya and Drits, 1970). The only known exception is ferric illite reported from an inferred deep marine setting within the Mesoproterozoic Penganga Group, India (Deb and Fukuoka, 1998); however, in this case the sources of $\mathrm{Fe}_{2} \mathrm{O}_{3}$ (total) and $\mathrm{MgO}$ are doubtful because of the presence of ferro-magnesian minerals in the host sandstones. $\mathrm{Fe}$ and $\mathrm{Mg}$ were apparently derived from the seawater in the paleoenvironment within the Mg-rich ferric illites of the Semri Group. It describes the glauconitic intervals within two marine segments of the Semri Group around Chopan, central India (Fig. 1A and B) in their respective stratigraphic context, and also the petrographic characteristics of glauconitic sandstones. We also present mineralogical and chemical characteristics of the glauconitic minerals, trace their apparent origin and ultimately focus upon the possible implications of the glauconitization in the Semri siliciclastics within the framework of their interpreted Precambrian epeiric sea genesis. It brings to the fore another striking fact that one of the two glauconitic intervals of the Semri group under focus here comprises the upper part of a HST. This observation is in direct contrast to the typical occurrence of the glauconitic family of minerals within TST deposits or, more expectedly, in condensed zone sedimentary rocks ([Amorosi, 1995], [Amorosi, 1997], [Amorosi and Centineo, 1997] and [Kitamura, 1998]).

\section{Geological background}

The Paleo- to Neoproterozoic Vindhyan Supergroup in central India is dominated by shallow marine siliciclastics and carbonates deposited in an epeiric sea, which opened to the west (Bose et al., 2001). An unconformity, laterally correlatable with a conformity, divides the roughly $4.5 \mathrm{~km}$-thick Vindhyan Supergroup into two parts, viz. the lower Vindhyan, also known as the Semri Group, and the upper Vindhyan (Fig. 2). The exposures of the Semri Group are fairly continuous along the southern limb of a westerly 
plunging broad syncline in the valley of the Son River, with discontinuous and limited outcrops on the northern limb (Fig. 1B). The Deoland Formation, at the base and the Chorhat Sandstone Member of the Kheinjua Formation, at the middle level of the Semri Group contain the ferric illites discussed in this paper (Fig. 2). The age of the Chorhat Sandstone is bracketed between 1.63 and $1.60 \mathrm{Ga}$ on the basis of U/Pb SHRIMP dating of zircon grains in the tuffaceous layers bounding the Kheinjua Formation immediately below and above (Rasmussen et al., 2002). Based on a detailed review of recent literature, Ray (2006) considered that the Chorhat Sandstone is slightly older than $1.6 \mathrm{Ga}$ and placed it within the Paleoproterozoic. Although there are no direct age data for the Deoland Formation, it is considered slightly older than $1.72 \mathrm{Ga}$ on the basis of $\mathrm{Sr}$ isotope stratigraphy of the Kajrahat Limestone in the Kajrahat Formation, immediately overlying it (Ray, 2006) (Fig. 2). Despite its age, the entire Vindhyan succession is unmetamorphosed and only mildly deformed (Bose et al., 2001). Vindhyan sedimentation commenced in an intracratonic rift setting that later transformed into a sag basin during upper Vindhyan time (Bose et al., 2001). Bose et al. (2001) presented a comprehensive paleogeographic synthesis for the entire Vindhyan Supergroup and provided a general outline of sequence stratigraphic architecture of the Semri basin in central India (Fig. 2). The succession in the Chopan study area varies only a little from this, with the recording of a locally developed terrestrial sediments at the base (see below). 


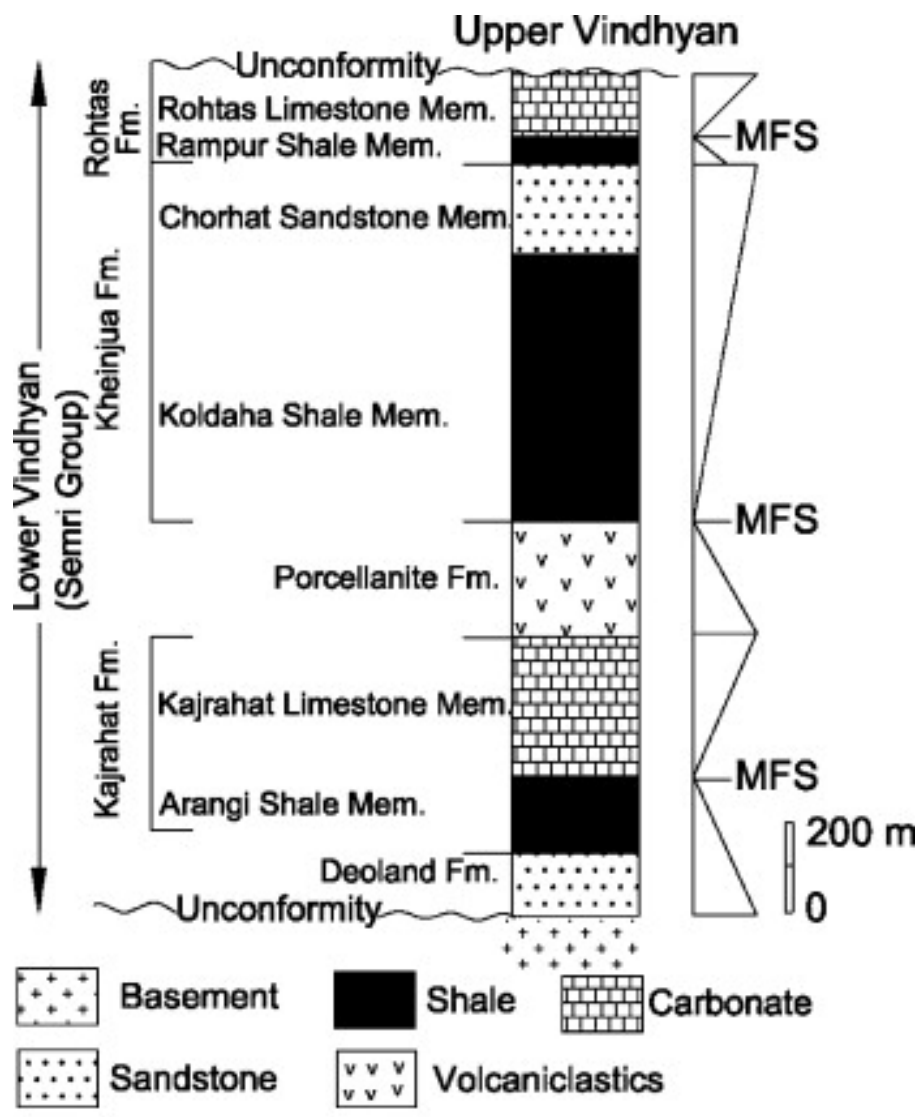

$\nabla$ highstand systems tract $\triangle_{\text {transgressive systems tract }}$ MFS = Maximum flooding surface

Fig. 2. Stratigraphic succession, lithological variation and depositional trends within the Semri Group.

Sedimentation in the Semri basin took place mostly in the marine realm, although there are local intervals and occurrences of fluvial and aeolian sediments ([Banerjee, 1997], [Bose et al., 2001], [Banerjee and Jeevankumar, 2005], [Sarkar et al., 2006] and [Jeevankumar, 2006]). Both the Deoland Formation and the Chorhat Sandstone contain non-marine sediments, but the green glauconitic minerals under discussion here occur within the marine portions only (Jeevankumar, 2006). 


\section{Laboratory methodologies}

Fresh samples were collected from quarries and river sections for the various laboratory studies. Thin sections of the glauconitic sandstones were examined and photographed using a Nikon Eclipse E 600 polarizing microscope with an attached Nikon coolpix 8700 digital camera. After mildly grinding the glauconitic sandstone samples the glauconitic pellets were hand-picked and powdered for XRD analysis. The powdered samples were scanned from $3^{\circ}$ to $60^{\circ}$ at $3^{\circ} 2 \theta \mathrm{min}^{-1}$ scan speed, using nickel filtered Copper $\mathrm{K} \alpha$ radiation in a Rigaku Geigerflex X-Ray Diffractometer at the Department of Earth Sciences, IIT Bombay. The samples were again scanned under the same instrumental setting after treatment with ethylene glycol vapor for $24 \mathrm{~h}$; the same samples were thermally heated up to $490{ }^{\circ} \mathrm{C}$ for $2 \mathrm{~h}$, and again scanned once more. Repeated X-ray analysis after various treatments of the samples was needed to distinguish glauconitic minerals from other clay minerals. SEM study of the selected green sandstone samples was carried out on polished thin sections using a JEOL JSM 840 scanning electron microscope with Kevex Winstation EDS at the Department of Earth Sciences, IIT Bombay.

Electron Probe Microanalysis of the same samples was carried out to determine composition of the glauconitic minerals and their substrates using a JEOL-JXA-8600 M Superprobe, with an accelerating voltage of $15 \mathrm{kV}$, specimen current of $20 \mathrm{nA}$ and beam diameter of $3 \mathrm{~mm}$, at the Institute Instrumentation Centre, IIT Roorkee. Multiple points were analyzed from the same thin section. Doubly polished thin sections were used for this purpose. A. garnet ( $\mathrm{Si}, \mathrm{Al}, \mathrm{Fe}), \mathrm{P}$. garnet $(\mathrm{Mg})$, bustamit $(\mathrm{Mn})$, diopside $(\mathrm{Ca})$, biotite $(\mathrm{K})$ and plagioclase $(\mathrm{Na})$ were used as standards. Duplicate analysis of individual points showed an analytical error of less than $1 \%$, which is associated with X-ray counting, standardization and correction uncertainties inherent to the technique. The ZAF method was followed to correct the EPMA data. 


\section{Studied formations and mode of occurrence of glauconitic minerals}

\subsection{Deoland formation}

The Deoland Formation, which is underlain by Archean phyllites in the study area and succeeded by the dark green-coloured Arangi Shale above, is an overall fining-upward siliciclastic succession (Jeevankumar, 2006) (Figs. 2 and 3A). A thin and broadly wavy granular sheet divides the Formation into two upward-fining successions, differing in lithology, texture, sand body geometry and internal structures (Figs. 3A and B and 4A-I). The lower 60 m-thick segment of the Deoland Formation consists dominantly of coarser grained sediments and is totally devoid of the glauconitic minerals. Local patches of fault breccia, with occasional matching boundaries between adjacent clasts, overlie the unconformity on top of the Archean basement rocks (Fig. 4A). Otherwise, the lower segment is made up of conglomerate and pebbly sandstone, both poorly sorted and possessing lenticular geometry, comparatively more pronounced in the former (Fig. 4BD). The conglomerates are internally massive, but with increasing incorporation of sandstone, become crudely cross-stratified, pebbles generally defining the foreset bases, but also being randomly scattered. The sandstone is thoroughly cross-stratified, except at the base of the segment where it is massive or poorly cross-stratified (Fig. 4D). Vertical juxtaposition of channel forms of these poorly sorted siliciclastic sedimentary rocks supports fluvial aggradation. The fining-upward trend in this lower Deoland stratigraphic segment reflects a slow rise in base level (cf. Catuneanu, 2002). Sandstone lenses with pebbles scattered randomly within them indicate intermittent high-energy flash-flood deposition (cf. Pfluger and Seilacher, 1991). 

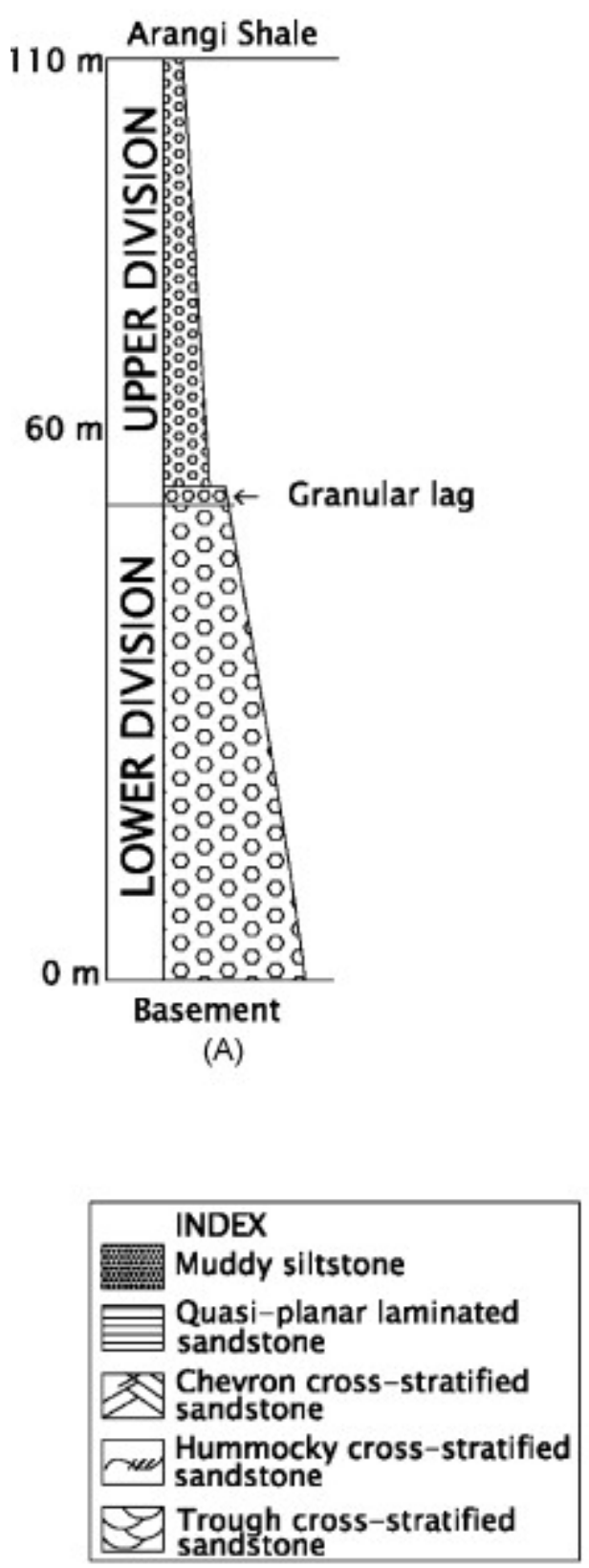

(B)

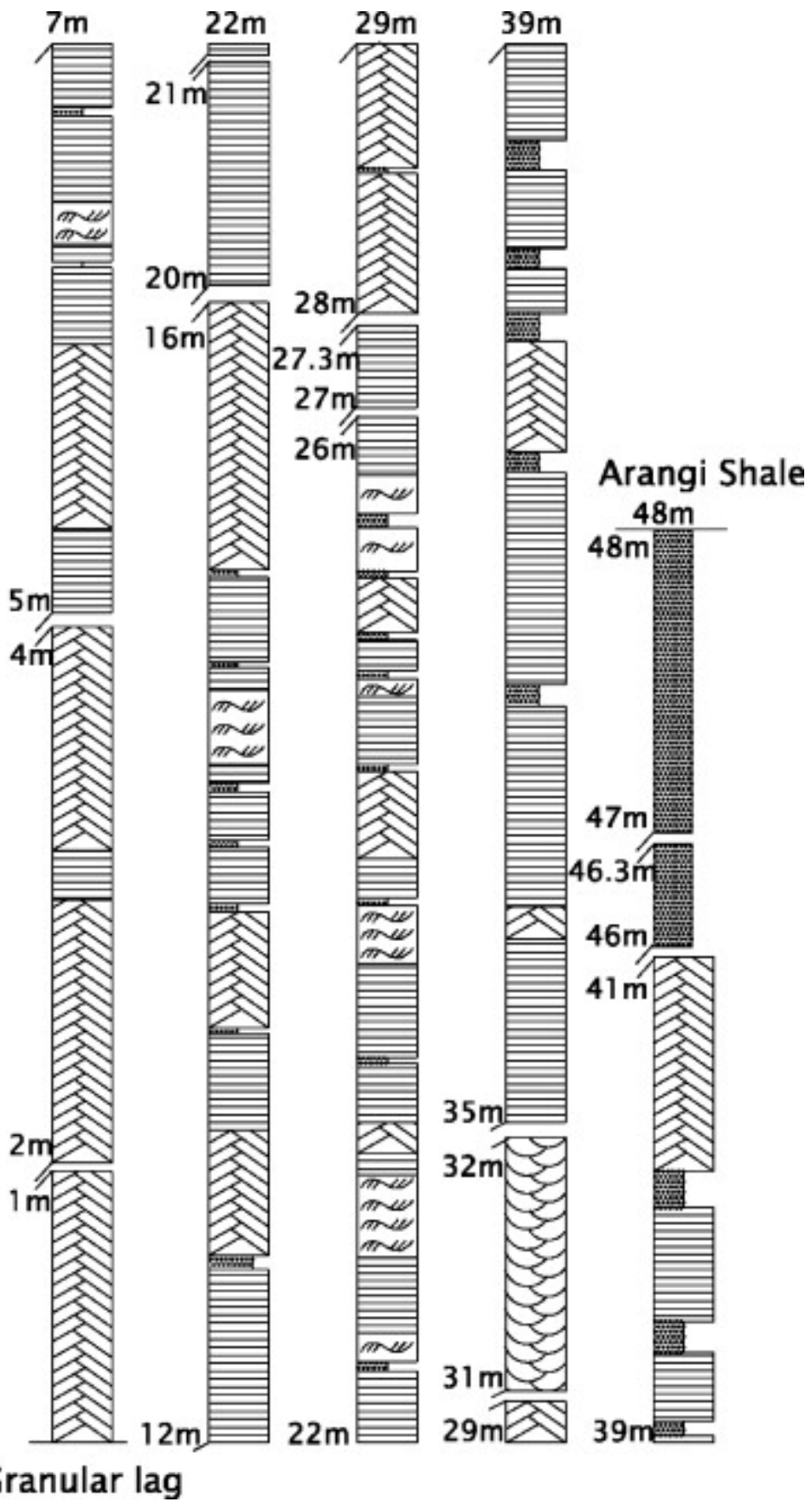

Fig. 3. Log showing two divisions of the Deoland Formation separated by a granular lag, and overall fining-upward succession (A). Detailed log showing vertical facies distribution within the upper segment of the Deoland Formation (B). 

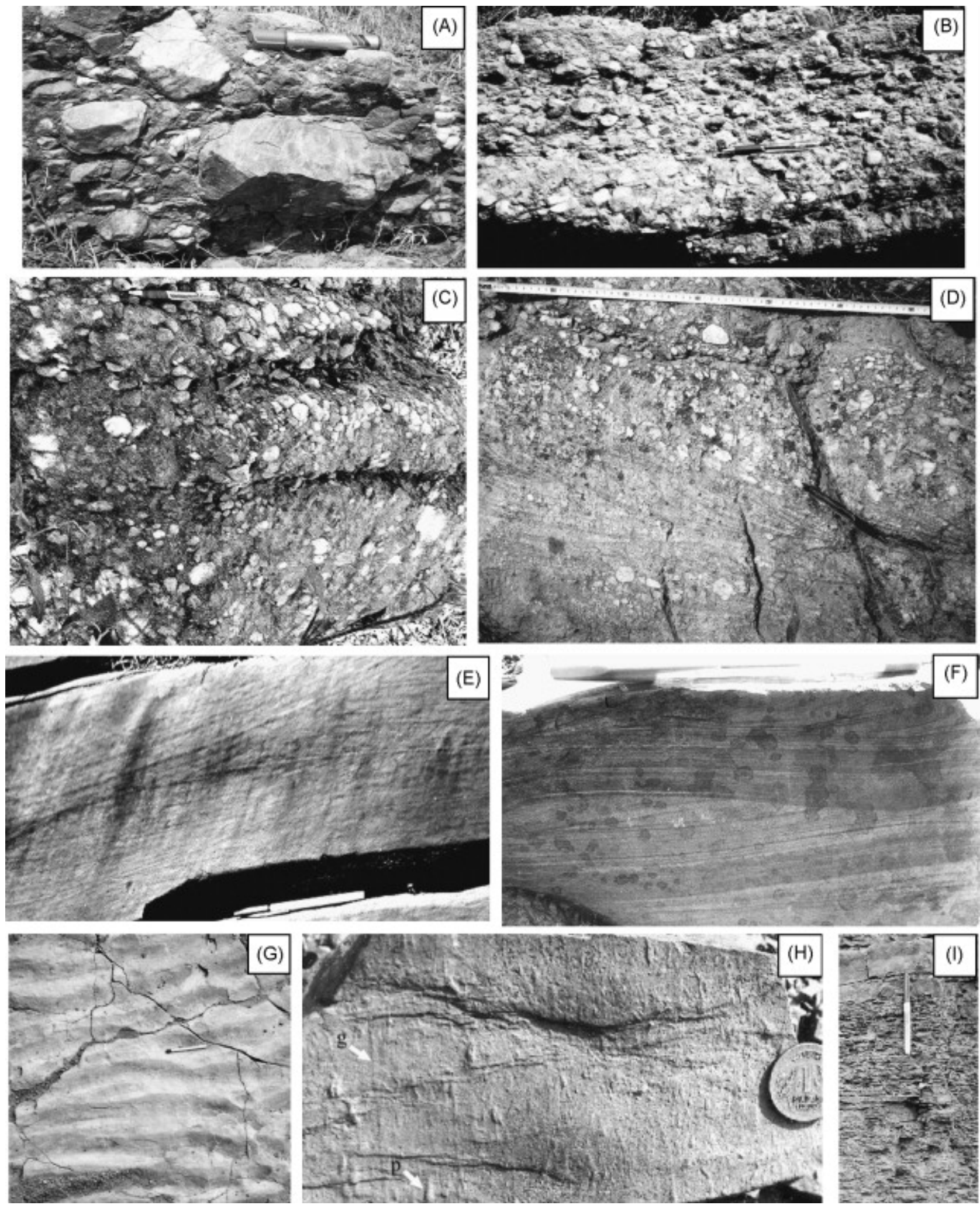

Fig. 4. Field photographs representing the lower (Figs. A-D) and the upper division

(Figs. E-I) of the Deoland Formation: breccia (A), conglomerate (B), vertical stacking of 
conglomerate beds (C) and cross-stratified pebble-bearing sandstone (D), chevron crossstratification (E), hummocky cross-stratification (F), wave ripples $(\mathrm{G})$, sole marks including groove cast-g and prod marks-p $(\mathrm{H})$ and shale-sandstone alternation at the top of the Deoland Formation (I) (scales: pen length in B-F $=14 \mathrm{~cm}$, match-stick length in $\mathrm{G}=4.5 \mathrm{~cm}$, marker pen in $\mathrm{A}$ and $\mathrm{I}=12 \mathrm{~cm}$, coin diameter in $\mathrm{H}=2.5 \mathrm{~cm}$ ).

In contrast, the $50 \mathrm{~m}$-thick upper Deoland stratigraphic segment are distinctly finergrained, progressively fine upward and consists dominantly of chevron cross-stratified sandstone, hummocky cross-stratified sandstone and planar laminated sandstone, with

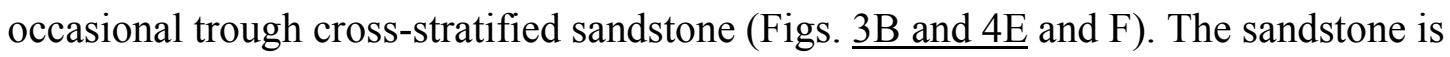
well-sorted and consists of well-rounded grains. The sandstone beds are tabular or sheetlike in their geometry. Straight-crested and bifurcated ripples frequently occur on top surface of the sandstone beds (Fig. 4G). The soles of the beds locally contain prod marks and groove casts (Fig. 4H). Sandstone of the upper segment is selectively glauconitized throughout, but no relation between glauconitic grains and stratification, such as glauconitic grains defining the foreset bases, is discernible. Muddy siltstone progressively dominates the upper part of this segment and becomes over thickened towards the top of this segment (Figs. 3B and 4I). The overall fining-upward lower segment gradationally passes over to the Arangi Shale of the Kajrahat Formation (Figs. 2 and 3A).

Abundance of wave-formed features including hummocky cross-strata, wave ripples, chevron cross-strata, quasi-planar strata and low angle trough cross-strata suggest that deposition of the upper part of the Deoland Formation took place on an open, strongly agitated shelf, which deepened through time. The granular lag at the base of the segment marks a ravinement surface that was created as a result of a substantial increase in the rate of base level or sea level rise than that noted before for the lower Deoland Formation. Transgression continued throughout the deposition of the upper Deoland Formation, to the Arangi shale of deep offshore affinity (Bose et al., 2001). The overall fining upward Deoland Formation and the Arangi Shale together forms a transgressive systems tract (Fig. 2; see also Bose et al., 2001). 


\subsection{Chorhat sandstone}

The Chorhat Sandstone Member, bounded between the organic carbon-rich Koldaha Shale Member (together forming the Kheinjua Formation) below and the Rampur Shale Member (Rohtas Formation) above (Fig. 2) shows a slightly coarsening-upward trend. Sarkar et al. (2006) described the facies constituents from the area around Chorhat in detail. The local occurrence of the eolianite found at the top of the formation at Chorhat is absent in the Chopan study area, but otherwise the facies constituents are nearly same for the two field areas.

The Chorhat Sandstone is entirely sandy, except for occasional thin partings of muddy siltstone between the sandstone beds (Figs. 5A and B and 6A-H). The lowermost facies (facies $\mathrm{A}$ ) is up to $9 \mathrm{~m}$ thick and is characterized by vertically stacked, $8-14 \mathrm{~cm}$ thick, overall graded, greenish, fine sandstone beds (Figs. 5B and 6A). The sandstone beds exhibits sheet-like geometry and locally alternates with thin siltstone beds. Internally the sandstone beds exhibit hummocky cross-stratification, planar lamination and wave ripples, and a few beds appearing massive (Figs. 5B and 6B). The soles of the sandstone beds are sharp and erosional, very often bearing gutter casts and prod marks (Fig. 6C). The overlying facies (facies B) is characterized by well-sorted and medium- to coarsegrained, grey sandstone. The sandstone beds of this are comparatively thicker $(>15 \mathrm{~cm})$ and are completely devoid of mud. Internally the sandstone beds exhibits hummocky cross-stratification and quasiplanar lamination. The majority of the sandstone beds are mantled by wave ripples with straight or broadly sinuous crests and asymmetric profiles (Fig. 6D). Amalgamation between sandstone beds is more common (Fig. 6G). Ripples migrating along troughs of larger ripples (ladder-back ripples) and interference ripples are confined to the upper $5 \mathrm{~m}$ comprising facies B of the Chorhat Sandstone (Figs. 6E and F). Emergence features such as rill marks, rünzel marks and desiccation cracks occur in profusion in this upper part (Fig. 6H). 

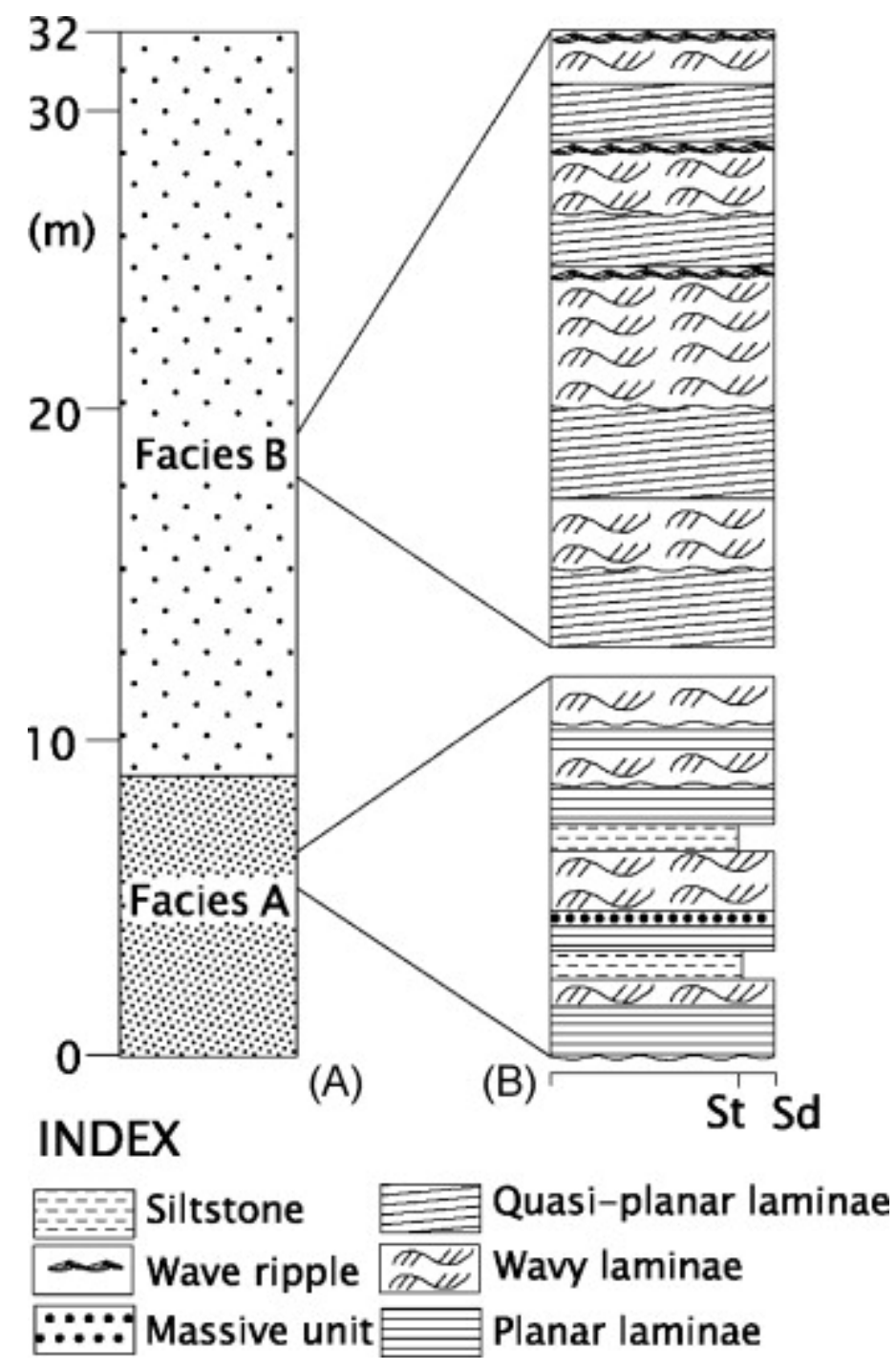

Fig. 5. Vertical log showing superposition of facies in the Chorhat Sandstone (A) and structural assemblage of individual facies (B). 

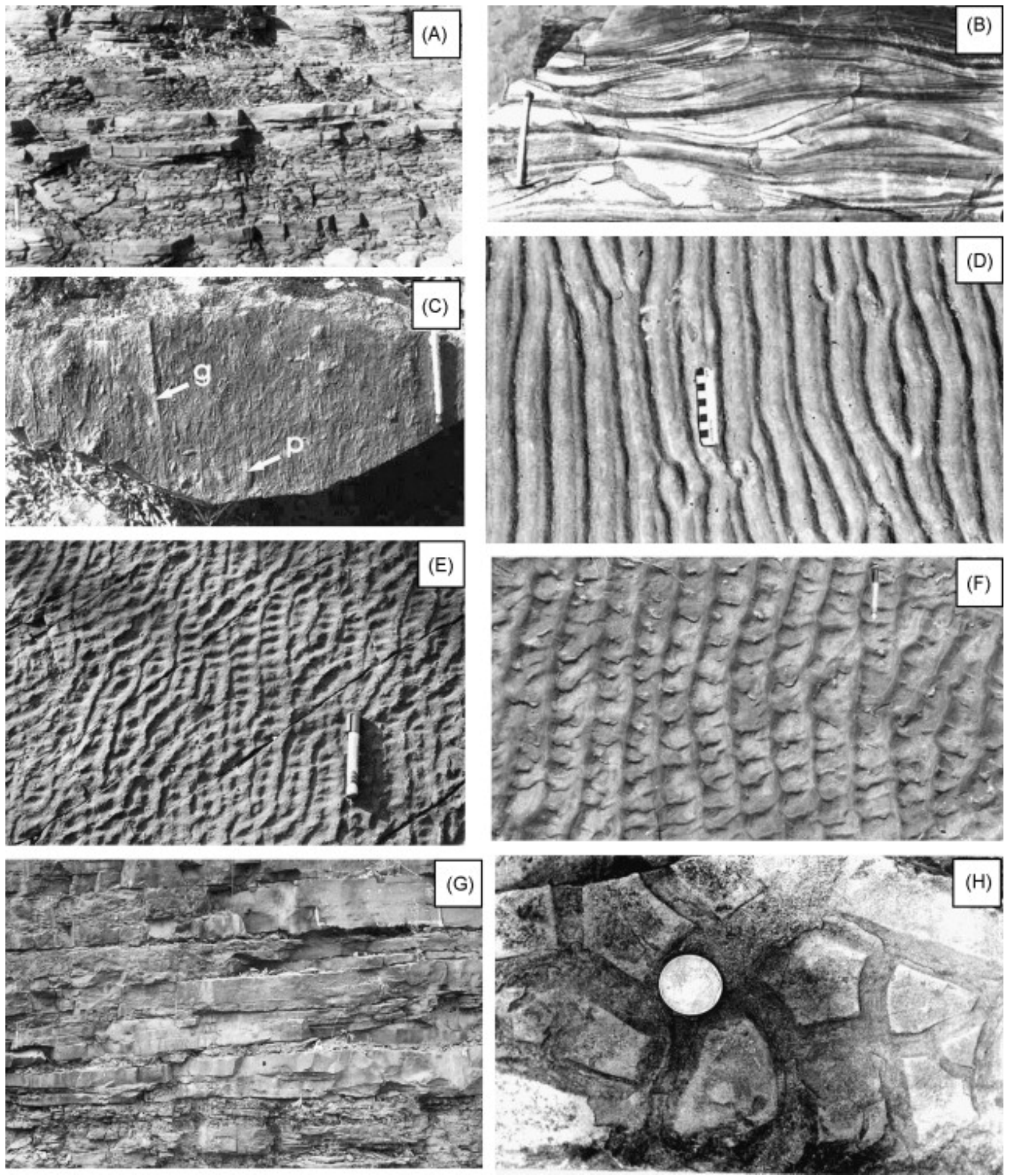

Fig. 6. Field photographs representing the Chorhat Sandstone (A-H): sheet-like, thin sandstone beds in the lower part (A), wavy laminated sandstone (B), sole marks at the base of a sandstone bed including grove casts-g and prod marks-p (C), wave ripples 
showing tuning-fork bifurcation and secondary ripples within the troughs of primary ripples (D), interference ripples $(\mathrm{E})$, ladder-back ripples $(\mathrm{F})$, thicker, amalgamated sandstone beds near the top part $(\mathrm{G})$ and desiccation cracks $(\mathrm{H})$. (Scales: pen length $=14 \mathrm{~cm}$, match-stick length $=4.5 \mathrm{~cm}$, coin diameter $=2.5 \mathrm{~cm})$.

Deposition of the Chorhat Sandstone is ascribed to a storm-dominated open sea paleoenvironment (Bose et al., 2001), based on the characteristics described above (cf. [Bourgeois, 1980], [Brenchley and Newall, 1982], [Hunter and Clifton, 1982] and [Hill et al., 2003] and many others). More frequent amalgamation of sandstone beds in the facies B points to shoaling. Ripples migrating along troughs of larger ripples at the topmost part of the section also indicates late stage run-off on emergence of the depositional surface. In contrast, occurrence of thin storm beds in facies A in the lower part of the Member suggests deposition near the storm-wave base (Seilacher et al., 1982). The Chorhat Sandstone, gradationally overlying the dominantly offshore-originated Koldaha Shale, thus appears to have developed from near the storm wave base, in its lower part, to a setting at the sea surface, in its upper part. The resultant sequence stratigraphic interpretation of the Chorhat Sandstone (Bose et al., 2001) encompasses a progradation leading to development of a HST, after maximum flooding at the base of the Kheinjua Formation (Fig. 2). Apparently sedimentation took place mostly by waves and during storms, in consistency with the seaward zone in the early Shaw (1964)-Irwin (1965) epeiric sea model. Wave energy is also generally accepted as having been predominant in classic epeiric seaway models, such as that for the Cretaceous Interior Seaway of North America (e.g., [Swift and Rice, 1984], [Oschmann, 1990] and [Krassay, 1994]). In contrast, (Eriksson et al., 1998), (Eriksson et al., 2001) and (Eriksson et al., 2005) argue in favour of a Precambrian epeiric embayment (smaller than epeiric seaways and thus not transcontinental in scale) model, where lower energy tidal-dominated deposition took place and where braided fluvial and braid-deltaic influences were significant in littoral regions.

Glauconitization of sandstones is confined to the lower $9 \mathrm{~m}$-thick facies A of the Chorhat Sandstone, while its upper part consisting of facies B contains very little of the green 
mineral. Apparently sandstones deposited near the storm wave base contain glauconitic minerals, whereas the nearshore sandstones do not. Here too, as in the Deoland Formation, the glauconitic grains distribution does not maintain any relation with stratification or visible sedimentary structures such as cross-beds.

\section{Petrography and XRD study of glauconitic rocks}

Glauconitic sandstones of the Deoland Formation and the Chorhat Sandstone Member exhibit common textural as well as mineralogical characteristics: well-sorted, quartz-rich sandstones (detrital feldspar ranging from 5 to $15 \%$ ); entirely devoid of any ferromagnesian minerals (e.g., Fig. 7A). Overgrowths formed around quartz and feldspar grains largely fill the interstitial spaces, matrix content never exceeds $10 \%$. Glauconitic minerals in the Deoland Formation (hereafter referred to as DFF) and the Chorhat Sandstone (hereafter referred to as CSF) also exhibit similar microscopic and submicroscopic features. Glauconitic minerals occur either as smooth, rounded to subrounded peloids, often bearing islets of relic feldspar (Figs. 7A and B), as streaks along cleavages and fractures within feldspar grains (Fig. 7C), or along the fringes of detrital grains of feldspar (Fig. 7D). The fractures are restricted to feldspars and do not extend into adjacent grains (Fig. 7E). In fact, the fractures are commonly initiated from the cleavage planes already filled by the glauconitic minerals, but rarely follow the weaker cleavage planes (Fig. 7E). Whether occurring along cleavages or fractures the glauconitic streaks have highly irregular boundaries (Fig. 7F). While the feldspar grains have been preferred for glauconitzation, overgrowths around them are generally spared (Fig. 7B and G). The glauconitic peloids are slightly larger than the associated quartz grains. Diameters of the rounded peloids range between 0.1 and $0.7 \mathrm{~mm}$; the long axes of the elliptical peloids have an average length of $0.8 \mathrm{~mm}$. No broken peloids have been encountered. DFF peloids generally appear paler than CSF peloids; the latter are mostly dark green. In plane polarized light, glauconitic peloids appear as yellowish green to dark green and are pleochroic. Under crossed nichols, the glauconitic minerals exhibit either aggregate or pinpoint extinctions and appear as cryptocrystalline to microcrystalline; the former is characterized by random arrangement of micro-platelets and the latter by fine, micro- granular internal constituents (Fig. 7H). 

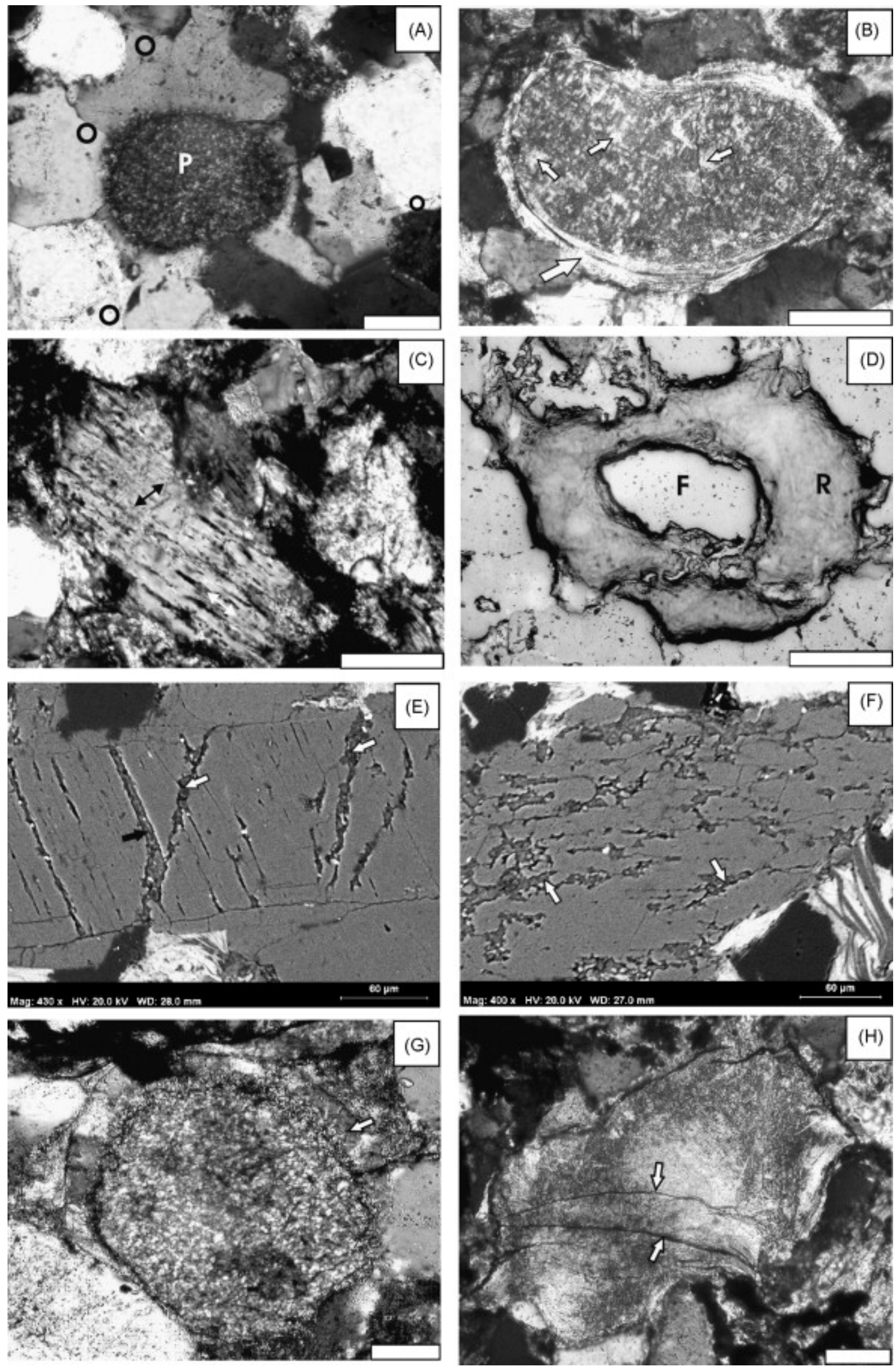
Fig. 7. Light microscope and SEM features of the ferric illites (A-H). Photomicrograph in transmitted light (crossed polars) showing quartz-rich, matrix free sandstone ( $\mathrm{P}=$ ferric illite peloid and $\mathrm{o}=$ quartz overgrowth, $\mathrm{bar}=0.2 \mathrm{~mm})(\mathrm{A})$, photomicrograph (transmitted light, crossed polars) of a ferric illite peloid bearing relics of precursor feldspars (marked by smaller, white arrows) and feldspar overgrowth around the peloid (marked by the larger white arrow) (bar $=0.3 \mathrm{~mm})(\mathrm{B})$, photomicrograph (transmitted light, crossed polars) showing ferric illite streaks along cleavages of feldspar (white arrow representing dominant direction and black arrow representing the dormant direction of glauconitization) $(\mathrm{bar}=0.3 \mathrm{~mm})(\mathrm{C})$, photomicrograph (transmitted light, plane polarized light) showing ferric illite rims $(\mathrm{R})$ around feldspar grains $(\mathrm{bar}=0.3 \mathrm{~mm})(\mathrm{D})$, SEM back-scattered image showing ferric illite streaks along cleavages (marked by black arrow) and fractures (marked by white arrows) (E), SEM back-scattered image showing streaks/blebs of ferric illites within feldspars and which exhibit irregular boundaries (marked by white arrows) (F), photomicrograph in transmitted light (crossed polars) showing feldspar overgrowth (white arrow) around ferric illite peloids (bar $=0.25 \mathrm{~mm}$ ) (G), photomicrograph in transmitted light (crossed polars) showing pin-point extinction and the fractures (marked by white arrows) (bar $=0.15 \mathrm{~mm}$ ) within the ferric peloid in centre.

The partially replaced, glauconitized grains show relict extinction of the feldspars and reveal various stages of glauconitization. SEM back scattered images clearly reveal initiation of the glauconitization as minute blebs (5-10 $\mu \mathrm{m}$ in width, a few tens of $\mu \mathrm{m}$ in length) within the feldspar cleavages (Fig. 7E and F). SEM study also reveals crack development within the host feldspars during glauconitization (Fig. 7E and F). It appears that initially glauconitization of feldspar took place in the form of small blebs along dominant cleavage planes. Resultant increase in grain volume led to formation of fractures (Fig. 7E, F, H). Glauconitization then extended further along both cleavages and fractures until the entire feldspar grain was replaced. Yet, most of the peloids reveal the existence of relics of feldspar within them (Fig. 7B). 
The occurrence of glauconitic peloids larger in size than the associated detrital grains, their intact forms, and the lack of any relationship of their spatial distribution with stratification render their in situ origin apparent. In partially glauconitized grains, authigenic overgrowth has developed uniformly over the host feldspar, both on the unaltered and the glauconitized parts. Heavily glauconitized peloids in places bear feldspar overgrowths which are completely unaffected. It is thus suggested that glauconitization took place at an early diagenetic stage, prior to the formation of feldspar overgrowths and the process ceased with elimination of pore spaces by overgrowth formation.

XRD patterns of both DFF and CSF peloid exhibit characteristic peaks of 'glauconitic minerals' (Fig. 8; Odin and Matter, 1981; Amorosi, 1997). The glauconitic peloids exhibit prominent basal reflection $\left(\begin{array}{lll}0 & 0 & 1\end{array}\right)$ at $10 \AA d$-spacing and relatively weaker basal reflection ( $\left(\begin{array}{lll}0 & 3\end{array}\right)$ at $3.3 \AA d$-spacing, which remains unchanged when glycolated, even heated up to $490^{\circ} \mathrm{C}$ for $2 \mathrm{~h}$ (Odin and Matter, 1981; Ireleand et al., 1983). X-ray pattern do not exhibit any $\left(\begin{array}{lll}0 & 0\end{array}\right)$ reflection at $5 \AA d$-spacing. Absence of $5 \AA$ peak rules out 'true illite' nature of the minerals and further supports their glauconitic nature (Moore and Reynolds, 1997).

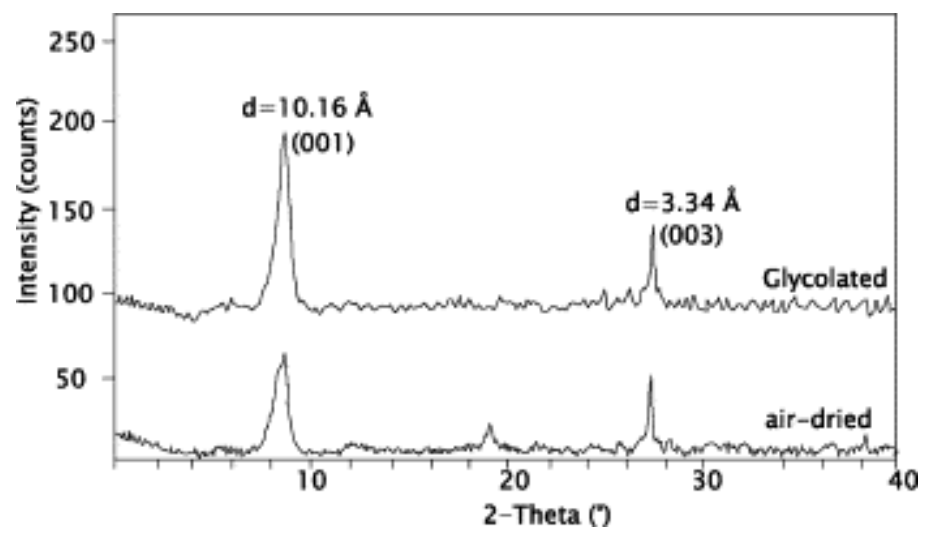

Fig. 8. X-ray pattern of the glauconitic minerals within the Chorhat Sandstone. Note that position of the basal peaks ( $\left.\begin{array}{lll}0 & 0 & 1\end{array}\right)$ and (l $\left.\begin{array}{lll}0 & 3\end{array}\right)$ remains unchanged in air dried (below) and glycolated samples (above). 


\section{Mineral chemistry of the 'glauconitic minerals' and their structures}

EPMA data of both the DFF and the CSF, including peloidal, tiny films of glauconitic minerals along the fringes of feldspar and along the cleavages and fractures of feldspars, are presented in Table 1 and in Fig. 9 and Fig. 10. The structural formula of the glauconitic minerals is calculated for the half unit cell of a mica structure on the basis of 10 oxygens and 2 hydroxyls, with a total of 22 negative charges (cf. Manghnani and Hower, 1964) and is presented in Table 2 . The cation content of all the analyzed phases is given in Table 3.

Table 1.

Oxide wt.\% of the glauconitic minerals measured by EPMA

\begin{tabular}{|l|l|l|l|l|l|l|l|l|l|}
\hline Sample no. & Point no. & $\mathbf{S i O}_{2}$ & $\mathbf{A l}_{2} \mathbf{O}_{3}$ & $\mathbf{F e}_{2} \mathbf{O}_{3}$ & $\mathbf{M g O}$ & $\mathbf{M n O}$ & $\mathbf{C a O}$ & $\mathbf{K}_{2} \mathbf{O}$ & $\mathbf{N a}_{2} \mathbf{O}$ \\
\hline D1-DFFP & 1 & 53.80 & 24.19 & 3.62 & 4.07 & 0.03 & 0.08 & 9.12 & 0.00 \\
\hline D1-DFFP & 2 & 52.40 & 25.03 & 2.41 & 3.78 & 0.00 & 0.09 & 9.54 & 0.00 \\
\hline D2-DFFP & 3 & 51.47 & 22.81 & 3.38 & 4.60 & 0.02 & 0.08 & 9.50 & 0.02 \\
\hline D2-DFFP & 4 & 58.56 & 22.32 & 4.01 & 7.01 & 0.01 & 0.10 & 4.10 & 0.00 \\
\hline D3-DFFP & 5 & 57.67 & 22.11 & 4.50 & 6.52 & 0.00 & 0.06 & 5.46 & 0.01 \\
\hline D3-DFFP & 6 & 52.36 & 28.14 & 3.87 & 3.23 & 0.00 & 0.03 & 6.53 & 0.07 \\
\hline D4-DFFP & 7 & 58.34 & 19.97 & 4.38 & 7.76 & 0.01 & 0.15 & 6.13 & 0.04 \\
\hline D5-DFFP & 8 & 57.70 & 22.02 & 3.84 & 7.15 & 0.02 & 0.15 & 5.64 & 0.04 \\
\hline D5-DFFR & 9 & 56.87 & 24.12 & 3.51 & 5.54 & 0.02 & 0.12 & 5.24 & 0.05 \\
\hline D5-DFFR & 10 & 57.16 & 24.77 & 3.67 & 5.11 & 0.00 & 0.05 & 5.26 & 0.05 \\
\hline D5-DFFR & 11 & 54.20 & 23.39 & 4.56 & 4.03 & 0.00 & 0.09 & 9.37 & 0.00 \\
\hline D5-DFFL & 12 & 57.99 & 28.52 & 2.42 & 3.52 & 0.04 & 0.07 & 5.32 & 0.03 \\
\hline D5-DFFL & 13 & 56.28 & 19.96 & 4.98 & 7.16 & 0.01 & 0.15 & 5.81 & 0.04 \\
\hline D5-DFFL & 14 & 50.21 & 21.27 & 3.19 & 5.71 & 0.00 & 0.15 & 6.91 & 0.05 \\
\hline
\end{tabular}




\begin{tabular}{|l|l|l|l|l|l|l|l|l|l|}
\hline Sample no. & Point no. & $\mathbf{S i O}_{2}$ & $\mathbf{A l}_{2} \mathbf{O}_{3}$ & $\mathbf{F e}_{2} \mathbf{O}_{3}$ & $\mathbf{M g O}$ & $\mathbf{M n O}$ & $\mathbf{C a O}$ & $\mathbf{K}_{2} \mathbf{O}$ & $\mathbf{N a}_{2} \mathbf{O}$ \\
\hline D5-DFF & 15 & 58.92 & 24.50 & 3.97 & 6.54 & 0.02 & 0.20 & 5.11 & 0.01 \\
\hline D5-DFFL & 16 & 52.07 & 30.10 & 5.57 & 1.90 & 0.04 & 0.00 & 6.15 & 0.05 \\
\hline C1-CSFP & 17 & 53.26 & 25.30 & 3.42 & 3.83 & 0.00 & 0.09 & 9.74 & 0.00 \\
\hline C1-CSFP & 18 & 53.18 & 22.63 & 6.15 & 5.28 & 0.00 & 0.11 & 9.25 & 0.00 \\
\hline C2-CSFP & 19 & 56.89 & 20.63 & 7.41 & 4.81 & 0.02 & 0.14 & 5.10 & 0.00 \\
\hline C2-CSFP & 20 & 58.77 & 25.02 & 5.49 & 3.39 & 0.00 & 0.13 & 5.52 & 0.05 \\
\hline C3-CSFP & 21 & 57.96 & 23.42 & 5.70 & 4.26 & 0.00 & 0.12 & 4.75 & 0.01 \\
\hline C4-CSFP & 22 & 57.04 & 15.44 & 9.51 & 6.19 & 0.02 & 0.15 & 7.53 & 0.04 \\
\hline C5-CSFP & 23 & 56.56 & 19.61 & 7.65 & 4.73 & 0.00 & 0.18 & 6.70 & 0.02 \\
\hline C5-CSFP & 24 & 51.28 & 19.97 & 9.91 & 3.47 & 0.03 & 0.22 & 8.97 & 0.07 \\
\hline C5-CSFP & 25 & 51.55 & 20.93 & 5.49 & 3.52 & 0.00 & 0.25 & 9.12 & 0.02 \\
\hline C6-CSFP & 26 & 54.24 & 16.14 & 9.76 & 5.47 & 0.00 & 0.24 & 9.19 & 0.04 \\
\hline C6-CSFR & 27 & 54.33 & 24.46 & 3.60 & 4.66 & 0.00 & 0.09 & 9.06 & 0.00 \\
\hline C6-CSFR & 28 & 60.15 & 17.07 & 9.13 & 6.09 & 0.03 & 0.14 & 5.03 & 0.02 \\
\hline C6-CSFR & 29 & 56.92 & 18.11 & 8.68 & 5.32 & 0.00 & 0.19 & 8.24 & 0.02 \\
\hline C6-CSFR & 30 & 54.25 & 19.47 & 9.04 & 4.27 & 0.03 & 0.17 & 9.05 & 0.07 \\
\hline C6-CSFL & 31 & 56.06 & 20.81 & 2.58 & 1.32 & 0.01 & 0.12 & 10.29 & 0.04 \\
\hline C6-CSFL & 32 & 53.71 & 24.03 & 5.18 & 3.26 & 0.01 & 0.22 & 7.05 & 0.00 \\
\hline C6-CSFL & 33 & 57.83 & 25.20 & 4.84 & 3.48 & 0.02 & 0.14 & 4.92 & 0.06 \\
\hline C6-CSFL & 34 & 52.06 & 24.38 & 3.24 & 3.84 & 0.03 & 0.08 & 9.21 & 0.04 \\
\hline
\end{tabular}

D1-D5: Samples from Deoland Formation, DFFP: ferric illite peloids, DFFR: ferric illite rims around feldspar, DFFL: ferric illites within the cleavages and fractures of feldspar. C1-C6: Samples from the Chorhat Sandstone, CSFP: ferric illite peloids, CSFR: ferric illite rims around feldspar, DFFL: ferric illites within the cleavages and fractures of feldspar. 


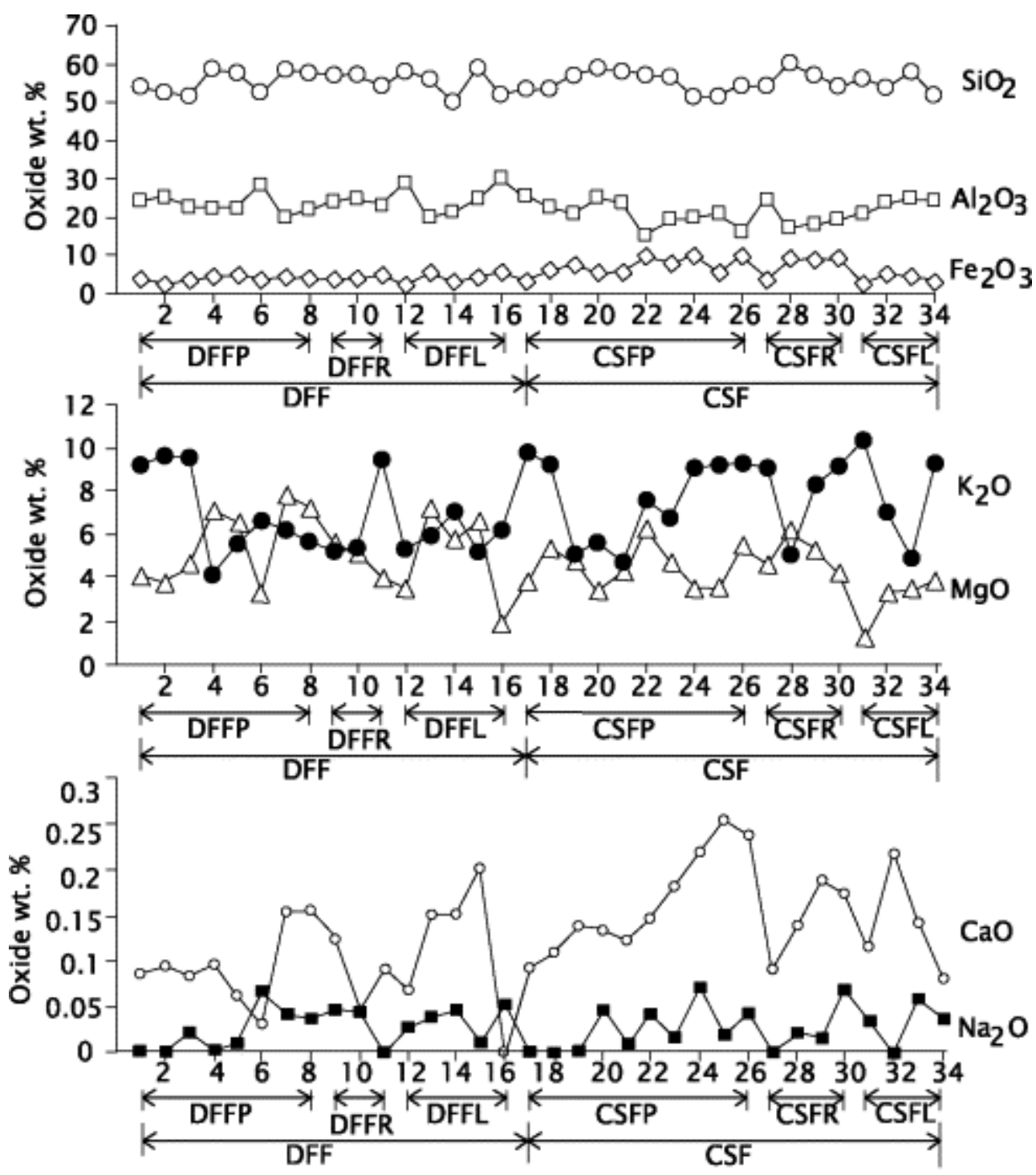

DFF $=$ Ferrie illites in Deoland Formation, DFFP $=$ Ferric illite peloids, DFFR $=$ Ferric illite rims around feldspar, DFFL=Ferric illites within the cleavages and fractures of feldspar, $\mathrm{CSF}=$ Ferrie illites in Chorhat Sandstone, CSFP=Ferric illite peloids, CSFR=Ferric ilite rims around feldspar, DEFL=Ferric illites within the cleavages and fratures of feldspar.

Fig. 9. Oxide (wt\%) content of the ferric illites at different points (For details see Table 1, points 1-8 = DFFP, 9-11 = DFFR, 12-16 = DFFL, 17-26 = CSFP, 27-30 = CSFR, 31-34 = CSFL). 

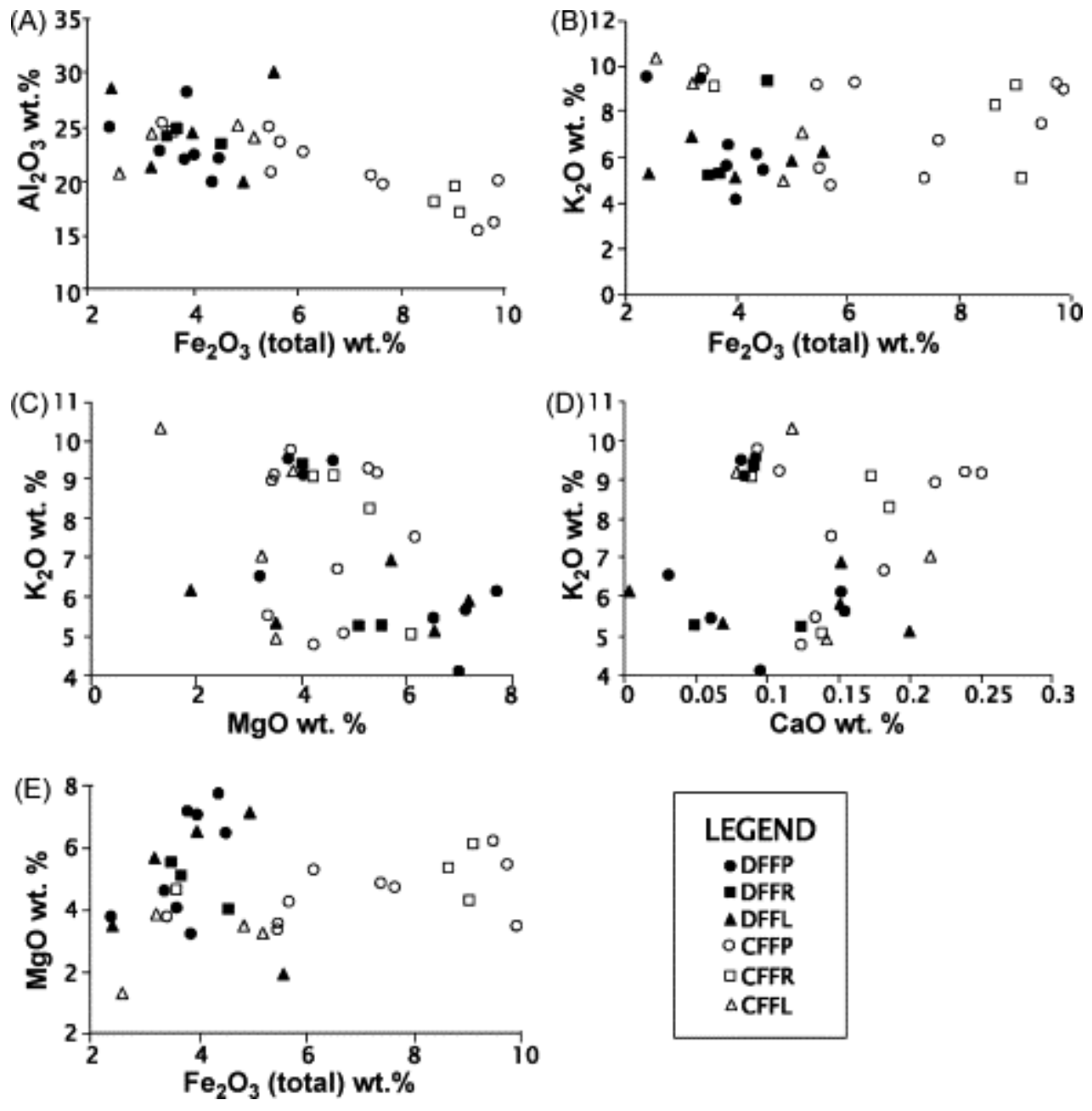

Fig. 10. Scatter plots between different oxides from the ferric illites of the Deoland Formation and the Chorhat Sandstone (A-E). For explanation of codes, see Fig. 9 and

\section{Table 1.}

Table 2.

Structural compositions of the glauconitic minerals recalculated from the EPMA data

\begin{tabular}{|l|l|}
\hline Sample no. & Structural composition \\
\hline D1-DFFP & $\mathrm{K}_{0.78}(\mathrm{Ca})_{0.01}\left(\mathrm{Al}_{1.53} \mathrm{Fe}^{3+}{ }_{0.09} \mathrm{Mg}_{0.41}\right)_{2.03}\left(\mathrm{Si}_{3.61} \mathrm{Al}_{0.39}\right)_{4} \mathrm{O}_{10}(\mathrm{OH})_{2 \mathrm{~s}}$ \\
\hline D1-DFFP & $\mathrm{K}_{0.83}(\mathrm{Ca})_{0.01}\left(\mathrm{Al}_{1.57} \mathrm{Fe}^{3+}{ }_{0.06} \mathrm{Mg}_{0.38}\right)_{2.01}\left(\mathrm{Si}_{3.56} \mathrm{Al}_{0.44}\right)_{4} \mathrm{O}_{10}(\mathrm{OH})_{2}$ \\
\hline D2-DFFP & $\mathrm{K}_{0.85}(\mathrm{Ca})_{0.01}\left(\mathrm{Al}_{1.17} \mathrm{Fe}^{3+}{ }_{0.09} \mathrm{Mg}_{0.48}\right)_{1.74}\left(\mathrm{Si}_{3.29} \mathrm{Al}_{0.71}\right)_{4} \mathrm{O}_{10}(\mathrm{OH})_{2}$ \\
\hline D2-DFFP & $\mathrm{K}_{0.34}(\mathrm{Ca})_{0.01}\left(\mathrm{Al}_{1.45} \mathrm{Fe}^{3+}{ }_{0.10} \mathrm{Mg}_{0.67}\right)_{2.22}\left(\mathrm{Si}_{3.76} \mathrm{Al}_{0.24}\right)_{4} \mathrm{O}_{10}(\mathrm{OH})_{2}$ \\
\hline
\end{tabular}




\begin{tabular}{|c|c|}
\hline Sample no. & Structural composition \\
\hline D3-DFFP & $\mathrm{K}_{0.45}\left(\mathrm{Al}_{1.43} \mathrm{Fe}^{3+}{ }_{0.11} \mathrm{Mg}_{0.63}\right)_{2.17}\left(\mathrm{Si}_{3.74} \mathrm{Al}_{0.26}\right)_{4} \mathrm{O}_{10}(\mathrm{OH})_{2}$ \\
\hline D3-DFFP & $\mathrm{K}_{0.56}(\mathrm{Na})_{0.01}\left(\mathrm{Al}_{1.70} \mathrm{Fe}^{3+}{ }_{0.10} \mathrm{Mg}_{0.32}\right)_{2.12}\left(\mathrm{Si}_{3.49} \mathrm{Al}_{0.51}\right)_{4} \mathrm{O}_{10}(\mathrm{OH})_{2}$ \\
\hline D4-DFFP & $\mathrm{K}_{0.51}\left(\mathrm{Na}_{0.01} \mathrm{Ca}_{0.01}\right)_{0.02}\left(\mathrm{Al}_{1.32} \mathrm{Fe}^{3+}{ }_{0.11} \mathrm{Mg}_{0.75}\right)_{2.18}\left(\mathrm{Si}_{3.79} \mathrm{Al}_{0.21}\right)_{4} \mathrm{O}_{10}(\mathrm{OH})_{2}$ \\
\hline D5-DFFP & $\mathrm{K}_{0.46}\left(\mathrm{Na}_{0.01} \mathrm{Ca}_{0.01}\right)_{0.02}\left(\mathrm{Al}_{1.41} \mathrm{Fe}^{3+}{ }_{0.9} \mathrm{Mg}_{0.69}\right)_{2.19}\left(\mathrm{Si}_{3.73} \mathrm{Al}_{0.27}\right)_{4} \mathrm{O}_{10}(\mathrm{OH})_{2}$ \\
\hline D5-DFFR & $\mathrm{K}_{0.43}\left(\mathrm{Na}_{0.01} \mathrm{Ca}_{0.01}\right)_{0.02}\left(\mathrm{Al}_{1.53} \mathrm{Fe}^{3+}{ }_{0.09} \mathrm{Mg}_{0.54}\right)_{2.16}\left(\mathrm{Si}_{3.69} \mathrm{Al}_{0.31}\right)_{4} \mathrm{O}_{10}(\mathrm{OH})_{2}$ \\
\hline D5-DFFR & $\mathrm{K}_{0.43}(\mathrm{Na})_{0.01}\left(\mathrm{Al}_{1.57} \mathrm{Fe}^{3+}{ }_{0.09} \mathrm{Mg}_{0.49}\right)_{2.15}\left(\mathrm{Si}_{3.69} \mathrm{Al}_{0.31}\right)_{4} \mathrm{O}_{10}(\mathrm{OH})_{2}$ \\
\hline D5-DFFR & $\mathrm{K}_{0.80}(\mathrm{Ca})_{0.01}\left(\mathrm{Al}_{1.50} \mathrm{Fe}^{3+}{ }_{0.12} \mathrm{Mg}_{0.40}\right)_{2.02}\left(\mathrm{Si}_{3.65} \mathrm{Al}_{0.35}\right)_{4} \mathrm{O}_{10}(\mathrm{OH})_{2}$ \\
\hline D5-DFFL & $\mathrm{K}_{0.42}\left(\mathrm{Al}_{1.72} \mathrm{Fe}^{3+}{ }_{0.06} \mathrm{Mg}_{0.33}\right)_{2.11}\left(\mathrm{Si}_{3.62} \mathrm{Al}_{0.38}\right)_{4} \mathrm{O}_{10}(\mathrm{OH})_{2}$ \\
\hline D5-DFFL & $\mathrm{K}_{0.50}\left(\mathrm{Na}_{0.01} \mathrm{Ca}_{0.01}\right)_{0.02}\left(\mathrm{Al}_{1.34} \mathrm{Fe}^{3+}{ }_{0.13} \mathrm{Mg}_{0.71}\right)_{2.18}\left(\mathrm{Si}_{3.77} \mathrm{Al}_{0.23}\right)_{4} \mathrm{O}_{10}(\mathrm{OH})_{2}$ \\
\hline D5-DFFL & $\mathrm{K}_{0.64}\left(\mathrm{Na}_{0.01} \mathrm{Ca}_{0.01}\right)_{0.02}\left(\mathrm{Al}_{1.44} \mathrm{Fe}^{3+}{ }_{0.09} \mathrm{Mg}_{0.61}\right)_{2.14}\left(\mathrm{Si}_{3.63} \mathrm{Al}_{0.37}\right)_{4} \mathrm{O}_{10}(\mathrm{OH})_{2}$ \\
\hline D5-DFFL & $\mathrm{K}_{0.41}(\mathrm{Ca})_{0.01}\left(\mathrm{Al}_{1.49} \mathrm{Fe}^{3+}{ }_{0.09} \mathrm{Mg}_{0.61}\right)_{2.19}\left(\mathrm{Si}_{3.68} \mathrm{Al}_{0.32}\right)_{4} \mathrm{O}_{10}(\mathrm{OH})_{2}$ \\
\hline D5-DFFL & $\mathrm{K}_{0.52}(\mathrm{Na})_{0.01}\left(\mathrm{Al}_{1.79} \mathrm{Fe}^{3+}{ }_{0.14} \mathrm{Mg}_{0.19}\right)_{2.12}\left(\mathrm{Si}_{3.44} \mathrm{Al}_{0.56}\right)_{4} \mathrm{O}_{10}(\mathrm{OH})_{2}$ \\
\hline C1-CSFP & $\mathrm{K}_{0.83}(\mathrm{Ca})_{0.01}\left(\mathrm{Al}_{1.55} \mathrm{Fe}^{3+}{ }_{0.09} \mathrm{Mg}_{0.32}\right)_{2.02}\left(\mathrm{Si}_{3.56} \mathrm{Al}_{0.44}\right)_{4} \mathrm{O}_{10}(\mathrm{OH})_{2}$ \\
\hline C1-CSFP & $\mathrm{K}_{0.80}(\mathrm{Ca})_{0.01}\left(\mathrm{Al}_{1.40} \mathrm{Fe}^{3+}{ }_{0.16} \mathrm{Mg}_{0.53}\right)_{2.09}\left(\mathrm{Si}_{3.60} \mathrm{Al}_{0.40}\right)_{4} \mathrm{O}_{10}(\mathrm{OH})_{2}$ \\
\hline C2-CSFP & $\mathrm{K}_{0.44}(\mathrm{Ca})_{0.01}\left(\mathrm{Al}_{1.45} \mathrm{Fe}^{3+}{ }_{0.19} \mathrm{Mg}_{0.48}\right)_{2.12}\left(\mathrm{Si}_{3.82} \mathrm{Al}_{0.18}\right)_{4} \mathrm{O}_{10}(\mathrm{OH})_{2}$ \\
\hline C2-CSFP & $\mathrm{K}_{0.45}(\mathrm{Ca})_{0.01}\left(\mathrm{Al}_{1.63} \mathrm{Fe}^{3+}{ }_{0.13} \mathrm{Mg}_{0.32}\right)_{2.08}\left(\mathrm{Si}_{3.75} \mathrm{Al}_{0.25}\right)_{4} \mathrm{O}_{10}(\mathrm{OH})_{2}$ \\
\hline C3-CSFP & $\mathrm{K}_{0.39}(\mathrm{Ca})_{0.01}\left(\mathrm{Al}_{1.57} \mathrm{Fe}^{3+}{ }_{0.14} \mathrm{Mg}_{0.41}\right)_{2.12}\left(\mathrm{Si}_{3.77} \mathrm{Al}_{0.23}\right)_{4} \mathrm{O}_{10}(\mathrm{OH})_{2}$ \\
\hline C4-CSFP & $\mathrm{K}_{0.66}\left(\mathrm{Na}_{0.01} \mathrm{Ca}_{0.01}\right)_{0.02}\left(\mathrm{Al}_{1.20} \mathrm{Fe}^{3+}{ }_{0.25} \mathrm{Mg}_{0.64}\right)_{2.09}\left(\mathrm{Si}_{3.94} \mathrm{Al}_{0.06}\right)_{4} \mathrm{O}_{10}(\mathrm{OH})_{2}$ \\
\hline C5-CSFP & $\mathrm{K}_{0.58}(\mathrm{Ca})_{0.01}\left(\mathrm{Al}_{1.41} \mathrm{Fe}^{3+}{ }_{0.20} \mathrm{Mg}_{0.48}\right)_{2.09}\left(\mathrm{Si}_{3.84} \mathrm{Al}_{0.16}\right)_{4} \mathrm{O}_{10}(\mathrm{OH})_{2}$ \\
\hline C5-CSFP & $\mathrm{K}_{0.82}\left(\mathrm{Na}_{0.01} \mathrm{Ca}_{0.02}\right)\left(\mathrm{Al}_{1.38} \mathrm{Fe}^{3+}{ }_{0.27} \mathrm{Mg}_{0.37}\right)_{2.02}\left(\mathrm{Si}_{3.69} \mathrm{Al}_{0.31}\right)_{4} \mathrm{O}_{10}(\mathrm{OH})_{2}$ \\
\hline C5-CSFP & $\mathrm{K}_{0.83}\left(\mathrm{Ca}_{0.02}\right)\left(\mathrm{Al}_{1.46} \mathrm{Fe}^{3+}{ }_{0.15} \mathrm{Mg}_{0.38}\right)_{1.99}\left(\mathrm{Si}_{3.69} \mathrm{Al}_{0.31}\right)_{4} \mathrm{O}_{10}(\mathrm{OH})_{2}$ \\
\hline C6-CSFP & $\mathrm{K}_{0.83}\left(\mathrm{Na}_{0.01} \mathrm{Ca}_{0.02}\right)_{0.03}\left(\mathrm{Al}_{1.20} \mathrm{Fe}^{3+}{ }_{0.26} \mathrm{Mg}_{0.58}\right)_{2.04}\left(\mathrm{Si}_{3.85} \mathrm{Al}_{0.15}\right)_{4} \mathrm{O}_{10}(\mathrm{OH})_{2}$ \\
\hline C6-CSFR & $\mathrm{K}_{0.77}(\mathrm{Ca})_{0.01}\left(\mathrm{Al}_{1.51} \mathrm{Fe}^{3+}{ }_{0.09} \mathrm{Mg}_{0.46}\right)_{2.06}\left(\mathrm{Si}_{3.60} \mathrm{Al}_{0.40}\right)_{4} \mathrm{O}_{10}(\mathrm{OH})_{2}$ \\
\hline C6-CSFR & $\mathrm{K}_{0.42}(\mathrm{Ca})_{0.01}\left(\mathrm{Al}_{1.31} \mathrm{Fe}^{3+}{ }_{0.23} \mathrm{Mg}_{0.60}\right)_{2.14}\left(\mathrm{Si}_{3.98} \mathrm{Al}_{0.02}\right)_{4} \mathrm{O}_{10}(\mathrm{OH})_{2}$ \\
\hline C6-CSFR & $\mathrm{K}_{0.71}(\mathrm{Ca})_{0.01}\left(\mathrm{Al}_{1.29} \mathrm{Fe}^{3+}{ }_{0.22} \mathrm{Mg}_{0.54}\right)_{2.05}\left(\mathrm{Si}_{3.85} \mathrm{Al}_{0.15}\right)_{4} \mathrm{O}_{10}(\mathrm{OH})_{2}$ \\
\hline
\end{tabular}




\begin{tabular}{|l|l|}
\hline Sample no. & Structural composition \\
\hline C6-CSFR & $\mathrm{K}_{0.80}\left(\mathrm{Na}_{0.01} \mathrm{Ca}_{0.01}\right)_{0.02}\left(\mathrm{Al}_{1.35} \mathrm{Fe}^{3+}{ }_{0.24} \mathrm{Mg}_{0.44}\right)_{2.03}\left(\mathrm{Si}_{3.76} \mathrm{Al}_{0.24}\right)_{4} \mathrm{O}_{10}(\mathrm{OH})_{2}$ \\
\hline C6-CSFL & $\mathrm{K}_{0.91}\left(\mathrm{Na}_{0.01} \mathrm{Ca}_{0.01}\right)_{0.02}\left(\mathrm{Al}_{1.59} \mathrm{Fe}^{3+}{ }_{0.7} \mathrm{Mg}_{0.14}\right)_{1.8}\left(\mathrm{Si}_{3.89} \mathrm{Al}_{0.11}\right)_{4} \mathrm{O}_{10}(\mathrm{OH})_{2}$ \\
\hline C6-CSFL & $\mathrm{K}_{0.61}(\mathrm{Ca})_{0.02}\left(\mathrm{Al}_{1.59} \mathrm{Fe}^{3+}{ }_{0.13} \mathrm{Mg}_{0.33}\right)_{2.05}\left(\mathrm{Si}_{3.66} \mathrm{Al}_{0.34}\right)_{4} \mathrm{O}_{10}(\mathrm{OH})_{2}$ \\
\hline C6-CSFL & $\mathrm{K}_{0.40}\left(\mathrm{Na}_{0.01} \mathrm{Ca}_{0.01}\right)_{0.02}\left(\mathrm{Al}_{1.65} \mathrm{Fe}^{3+}{ }_{0.12} \mathrm{Mg}_{0.33}\right)_{2.1}\left(\mathrm{Si}_{3.73} \mathrm{Al}_{0.27}\right)_{4} \mathrm{O}_{10}(\mathrm{OH})_{2}$ \\
\hline C6-CSFL & $\mathrm{K}_{0.81}\left(\mathrm{Na}_{0.01} \mathrm{Ca}_{0.01}\right)_{0.02}\left(\mathrm{Al}_{1.54} \mathrm{Fe}^{3+}{ }_{0.08} \mathrm{Mg}_{0.39}\right)_{2.01}\left(\mathrm{Si}_{3.57} \mathrm{Al}_{0.43}\right)_{4} \mathrm{O}_{10}(\mathrm{OH})_{2}$ \\
\hline
\end{tabular}

For explanation of codes see Table 1.

Table 3.

Cation content of the glauconitic minerals analyzed by EPMA

\begin{tabular}{|l|l|l|l|l|l|l|l|l|l|}
\hline Sample No. & Si & Al & Fe3+ & Mg & Mn & Ca & K & Na & Total \\
\hline D1-DFFP & 3.61 & 1.92 & 0.09 & 0.41 & 0.00 & 0.01 & 0.78 & 0.00 & 6.82 \\
\hline D1-DFFP & 3.56 & 2.01 & 0.06 & 0.38 & 0.00 & 0.01 & 0.83 & 0.00 & 6.85 \\
\hline D2-DFFP & 3.29 & 1.88 & 0.09 & 0.48 & 0.00 & 0.01 & 0.85 & 0.00 & 6.89 \\
\hline D2-DFFP & 3.76 & 1.69 & 0.10 & 0.67 & 0.00 & 0.01 & 0.34 & 0.00 & 6.56 \\
\hline D3-DFFP & 3.74 & 1.69 & 0.11 & 0.63 & 0.00 & 0.00 & 0.45 & 0.00 & 6.64 \\
\hline D3-DFFP & 3.49 & 2.21 & 0.10 & 0.32 & 0.00 & 0.00 & 0.56 & 0.01 & 6.69 \\
\hline D4-DFFP & 3.79 & 1.53 & 0.11 & 0.75 & 0.00 & 0.01 & 0.51 & 0.01 & 6.70 \\
\hline D5-DFFP & 3.73 & 1.68 & 0.09 & 0.69 & 0.00 & 0.01 & 0.46 & 0.01 & 6.67 \\
\hline D5-DFFP & 3.69 & 1.84 & 0.09 & 0.54 & 0.00 & 0.01 & 0.43 & 0.01 & 6.61 \\
\hline D5-DFFR & 3.69 & 1.88 & 0.09 & 0.49 & 0.00 & 0.00 & 0.43 & 0.01 & 6.59 \\
\hline D5-DFFR & 3.65 & 1.85 & 0.12 & 0.40 & 0.00 & 0.01 & 0.80 & 0.00 & 6.83 \\
\hline D5-DFFR & 3.62 & 2.10 & 0.06 & 0.33 & 0.00 & 0.00 & 0.42 & 0.00 & 6.54 \\
\hline D5-DFFL & 3.77 & 1.57 & 0.13 & 0.71 & 0.00 & 0.01 & 0.50 & 0.01 & 6.70 \\
\hline D5-DFFL & 3.63 & 1.81 & 0.09 & 0.61 & 0.00 & 0.01 & 0.64 & 0.01 & 6.79 \\
\hline D5-DFFL & 3.68 & 1.81 & 0.09 & 0.61 & 0.00 & 0.01 & 0.41 & 0.00 & 6.62 \\
\hline
\end{tabular}




\begin{tabular}{|l|l|l|l|l|l|l|l|l|l|}
\hline Sample No. & Si & Al & $\mathbf{F e 3}$ & $\mathbf{M g}$ & $\mathbf{M n}$ & $\mathbf{C a}$ & $\mathbf{K}$ & $\mathbf{N a}$ & Total \\
\hline D5- DFFL & 3.44 & 2.35 & 0.14 & 0.19 & 0.00 & 0.00 & 0.52 & 0.01 & 6.64 \\
\hline C1-CSFP & 3.56 & 1.99 & 0.09 & 0.38 & 0.00 & 0.01 & 0.83 & 0.00 & 6.86 \\
\hline C1-CSFP & 3.60 & 1.80 & 0.16 & 0.53 & 0.00 & 0.01 & 0.80 & 0.00 & 6.90 \\
\hline C2-CSFP & 3.82 & 1.63 & 0.19 & 0.48 & 0.00 & 0.01 & 0.44 & 0.00 & 6.58 \\
\hline C2-CSFP & 3.75 & 1.88 & 0.13 & 0.32 & 0.00 & 0.01 & 0.45 & 0.00 & 6.54 \\
\hline C3-CSFP & 3.77 & 1.80 & 0.14 & 0.41 & 0.00 & 0.01 & 0.39 & 0.00 & 6.53 \\
\hline C4-CSFP & 3.94 & 1.26 & 0.25 & 0.64 & 0.00 & 0.01 & 0.66 & 0.01 & 6.76 \\
\hline C5-CSFP & 3.84 & 1.57 & 0.20 & 0.48 & 0.00 & 0.01 & 0.58 & 0.00 & 6.67 \\
\hline C5-CSFP & 3.69 & 1.69 & 0.27 & 0.37 & 0.00 & 0.02 & 0.82 & 0.01 & 6.88 \\
\hline C5-CSFP & 3.69 & 1.77 & 0.15 & 0.38 & 0.00 & 0.02 & 0.83 & 0.00 & 6.84 \\
\hline C6-CSFP & 3.85 & 1.35 & 0.26 & 0.58 & 0.00 & 0.02 & 0.83 & 0.01 & 6.89 \\
\hline C6-CSFR & 3.60 & 1.91 & 0.09 & 0.46 & 0.00 & 0.01 & 0.77 & 0.00 & 6.83 \\
\hline C6-CSFR & 3.98 & 1.33 & 0.23 & 0.60 & 0.00 & 0.01 & 0.42 & 0.00 & 6.57 \\
\hline C6-CSFR & 3.85 & 1.44 & 0.22 & 0.54 & 0.00 & 0.01 & 0.71 & 0.00 & 6.78 \\
\hline C6-CSFR & 3.76 & 1.59 & 0.24 & 0.44 & 0.00 & 0.01 & 0.80 & 0.01 & 6.85 \\
\hline C6-CSFL & 3.89 & 1.70 & 0.07 & 0.14 & 0.00 & 0.01 & 0.91 & 0.01 & 6.72 \\
\hline C6-CSFL & 3.66 & 1.93 & 0.13 & 0.33 & 0.00 & 0.02 & 0.61 & 0.00 & 6.68 \\
\hline C6-CSFL & 3.73 & 1.92 & 0.12 & 0.33 & 0.00 & 0.01 & 0.40 & 0.01 & 6.52 \\
\hline C6-CSFL & 3.57 & 1.97 & 0.08 & 0.39 & 0.00 & 0.01 & 0.81 & 0.01 & 6.84 \\
\hline
\end{tabular}

For explanation of codes see Table 1.

$\mathrm{K}_{2} \mathrm{O}$ content of the minerals varies between 4.1 and $9.7 \%$, but does not show any relation with the stage of the glauconitization process, as values derived from glauconitic peloids, thin films within cleavages and fractures, and from rims of glauconitic minerals around feldspars overlap (Table 1, Fig. 9). The same is true for $\mathrm{Fe}_{2} \mathrm{O}_{3}$ (total) content which ranges from 2.4 to $9.8 \%$ in the peloids and from 2.4 to $7.5 \%$ in the thin films. However, $\mathrm{Fe}_{2} \mathrm{O}_{3}$ (total) is noticeably higher in the CSF (average 6.5\%) as compared to the DFF 
(average 3.9\%) (Table 1, Fig. 9). $\mathrm{Fe}_{2} \mathrm{O}_{3}$ (total) is lower than that of the 'true' glauconites of Odin and Matter (1981). In contrast, $\mathrm{Al}_{2} \mathrm{O}_{3}$ content is comparatively higher, varying from 15.4 to $30.1 \%$ (averaging $22.5 \%$ ), DFF being comparatively richer than the CSF. $\mathrm{MgO}$ content is up to $7.2 \%$ (average $4.7 \%$ ) and is perfectly comparable to that of 'mature' glauconitic minerals (Odin and Matter, 1981). $\mathrm{SiO}_{2}$ content of the glauconitic minerals varies from 50.2 to $60.2 \%$ (average $55.4 \%$ ) while $\mathrm{MnO}, \mathrm{Na}_{2} \mathrm{O}$ and $\mathrm{CaO}$ contents are negligible. $\mathrm{K}_{2} \mathrm{O}$ contents of the minerals are comparable to 'mature' glauconites described by Odin and Matter (1981) (average 7.2\%). The high $\mathrm{K}_{2} \mathrm{O}$ content distinguishes the minerals from illites, placing them in the mica group, whereas the low $\mathrm{Fe}_{2} \mathrm{O}_{3}$ (total) and high $\mathrm{Al}_{2} \mathrm{O}_{3}$ identifies them as ferric illites ([Dasgupta et al., 1990] and [Deb and Fukuoka, 1998]) or high-alumina glauconites (Berg-Madsen, 1983). The high MgO content of the minerals is, nevertheless, interesting as the host sandstones are devoid of ferro-magnesian minerals (cf. Deb and Fukuoka, 1998).

A cross plot involving $\mathrm{Al}_{2} \mathrm{O}_{3}$ and $\mathrm{Fe}_{2} \mathrm{O}_{3}$ (total) exhibits negative correlation, which is more pronounced in case of glauconitic peloids. The predominantly inverse relationship between $\mathrm{Al}_{2} \mathrm{O}_{3}$ and $\mathrm{Fe}_{2} \mathrm{O}_{3}$ (total) observed in both $\mathrm{DFF}$ and $\mathrm{CSF}$ is attributable to the predominant $\mathrm{Al}^{3+}-\mathrm{Fe}^{3+}$ substitution in glauconitic minerals (Fig. 10A; [Odin and Matter, 1981], [Ireland et al., 1983], [Velde, 1985], [Dasgupta et al., 1990] and [Jarrar et al., 2000]). Lack of any correlation between $\mathrm{K}_{2} \mathrm{O}$ and $\mathrm{Fe}_{2} \mathrm{O}_{3}$ (total) in these phases negates concomitant fixation of interlayer cations during replacement of other cations as described by other workers ([Valeton et al., 1982] and [Jarrar et al., 2000]) (Fig. 10B), but suggests independent incorporation of interlayer cations during glauconitization. Poor correlation is also observed between $\mathrm{K}_{2} \mathrm{O}$ and $\mathrm{MgO}$ (Fig. 10C) and between $\mathrm{K}_{2} \mathrm{O}$ and $\mathrm{CaO}$ (Fig. 10D), in contrast to Jarrar et al. (2000) who found good correlation for these oxides. Higher $\mathrm{Fe}_{2} \mathrm{O}_{3}$ (total) content distinguishes the CSF peloids from the DFF peloids in the scatter plots (Fig. 10A, B, E). Since the CSF peloids are darker, the color of the ferric illite peloids is seen to be closely related to their $\mathrm{Fe}_{2} \mathrm{O}_{3}$ (total) content.

Structural formulae of the analyzed phases are consistent with that of the glauconite family of minerals. As per AIPEA definition, glauconite is an Fe-rich dioctahedral mica 
with tetrahedral $\mathrm{Al}$ (or $\mathrm{Fe}^{3+}$ ) usually greater than 0.2 atoms per formula unit and octahedral $\mathrm{R}^{3+}$ correspondingly greater than 1.2 atoms (Bailey, 1980). Most of our data show higher than $0.2 \mathrm{Al}$ atoms per formula unit in the tetrahedral site. In the octahedral site, $\mathrm{Al}^{3+}$ is the major cation, varying between 1.17 and 1.79 (average 1.47), whereas the total $\mathrm{Fe}^{3+}$ is comparatively less, varying from 0.08 to 0.27 (average 0.13 ) atoms per formula unit. The octahedral $\mathrm{R}^{3+}$ varies from 1.26 to 1.93 atoms, with an average of 1.61 atoms per formula unit. $\mathrm{Mg}^{2+}$ is higher (average 0.47) than the published values (Jarrar et al., 2000). $\mathrm{Mn}^{2+}$ is negligible in the minerals and is not represented in the formula. In the analyzed phases, the tetrahedral sites are never completely filled by $\mathrm{Si} ; 92.5 \%$ of the four sites on average are occupied by $\mathrm{Si}$ and the rest is filled by Al. The average $\mathrm{Si}^{4+}$ and $\mathrm{Al}^{\mathrm{IV}}$ content of the tetrahedral site is 3.7 and 0.3 atoms per formula unit, respectively (Table 2). EPMA data of the ferric illite peloids and thin films of ferric illites along the cleavage planes and fringes of feldspars do not reveal any significant variation of cations.

The feldspars hosting the ferric illites are identified as K-feldspar, on the basis of their high $\mathrm{K}_{2} \mathrm{O}$ content as compared to their very low $\mathrm{Na}_{2} \mathrm{O}$ content (0.2 and 0.7) (Table 4). Kfeldspar overgrowth is almost similar in composition to the detrital grains. The cation content of all the analyzed potassium feldspar precursors is given in Table 5. The analysis was done on the basis of one unit cell of potassium feldspar, calculated for 8 oxygen atoms with a total negative charge of 16 .

Table 4 .

Oxide wt.\% of the feldspar precursors containing the blebs of ferric illite

\begin{tabular}{|l|l|l|l|l|l|l|l|l|l|}
\hline Sample no. & $\mathrm{SiO}_{2}$ & $\mathrm{Al}_{2} \mathbf{O}_{3}$ & $\mathbf{F e O}$ & $\mathbf{M g O}$ & $\mathbf{M n O}$ & $\mathbf{C a O}$ & $\mathbf{K}_{2} \mathbf{O}$ & $\mathbf{N a}_{2} \mathbf{O}$ & Total \\
\hline D2-FL (O) & 64.66 & 18.37 & 0.14 & 0.00 & 0.00 & 0.02 & 15.53 & 0.66 & 99.38 \\
\hline D2-FL & 68.95 & 17.63 & 0.04 & 0.00 & 0.00 & 0.00 & 12.99 & 0.02 & 99.63 \\
\hline D3-FL (O) & 64.96 & 18.45 & 0.02 & 0.00 & 0.00 & 0.00 & 16.36 & 0.21 & 99.99 \\
\hline D3-FL & 64.73 & 18.34 & 0.27 & 0.00 & 0.00 & 0.00 & 16.36 & 0.12 & 99.81 \\
\hline D5-FL & 65.22 & 18.42 & 0.05 & 0.00 & 0.00 & 0.00 & 16.15 & 0.29 & 100.13 \\
\hline C5-FL & 65.08 & 17.97 & 0.09 & 0.00 & 0.00 & 0.02 & 15.66 & 0.61 & 99.42 \\
\hline
\end{tabular}




\begin{tabular}{|l|l|l|l|l|l|l|l|l|l|}
\hline Sample no. & $\mathrm{SiO}_{2}$ & $\mathrm{Al}_{2} \mathbf{O}_{3}$ & $\mathbf{F e O}$ & $\mathrm{MgO}$ & $\mathbf{M n O}$ & $\mathrm{CaO}$ & $\mathrm{K}_{2} \mathbf{O}$ & $\mathrm{Na}_{2} \mathrm{O}$ & Total \\
\hline C5-FL & 66.19 & 18.00 & 0.16 & 0.00 & 0.01 & 0.05 & 14.81 & 0.19 & 99.41 \\
\hline C5-FL (O) & 66.00 & 17.04 & 0.07 & 0.00 & 0.00 & 0.00 & 17.31 & 0.00 & 100.42 \\
\hline C5-FL & 67.90 & 17.96 & 0.11 & 0.00 & 0.00 & 0.00 & 13.15 & 0.03 & 99.16 \\
\hline
\end{tabular}

Table 5.

Cation content of the feldspar precursors containing the blebs of ferric illite (calculated on the basis of 8 oxygen atoms)

\begin{tabular}{|l|l|l|l|l|l|l|l|l|l|}
\hline Sample no. & Si & Al & $\mathbf{F e}^{2+}$ & $\mathbf{M g}$ & $\mathbf{M n}$ & $\mathbf{C a}$ & $\mathbf{K}$ & $\mathbf{N a}$ & Total \\
\hline D2-FL (O) & 3.00 & 1.00 & 0.00 & 0.00 & 0.00 & 0.00 & 0.91 & 0.06 & 4.97 \\
\hline D2-FL & 3.10 & 0.93 & 0.00 & 0.00 & 0.00 & 0.00 & 0.75 & 0.00 & 4.78 \\
\hline D3-FL (O) & 3.00 & 1.00 & 0.00 & 0.00 & 0.00 & 0.00 & 0.96 & 0.02 & 4.98 \\
\hline D3-FL & 3.00 & 1.00 & 0.01 & 0.00 & 0.00 & 0.00 & 0.97 & 0.01 & 4.99 \\
\hline D5-FL & 3.00 & 1.00 & 0.00 & 0.00 & 0.00 & 0.00 & 0.95 & 0.03 & 4.98 \\
\hline C5-FL & 3.02 & 0.98 & 0.00 & 0.00 & 0.00 & 0.00 & 0.93 & 0.05 & 4.98 \\
\hline C5-FL & 3.04 & 0.98 & 0.00 & 0.00 & 0.00 & 0.00 & 0.87 & 0.01 & 4.90 \\
\hline C5-FL (O) & 3.05 & 0.93 & 0.00 & 0.00 & 0.00 & 0.00 & 1.02 & 0.00 & 5.00 \\
\hline C5-FL & 3.09 & 0.96 & 0.00 & 0.00 & 0.00 & 0.00 & 0.76 & 0.00 & 4.81 \\
\hline
\end{tabular}

For Table 4 and Table 5 D2, D3 and D5 are feldspars within the Deoland Formation, C5 is a feldspar within the Chorhat Sandstone, O: overgrowth. 
openUP (April 2008)

\section{Origin of the 'glauconitic minerals' in the Semri}

\section{group}

The glauconitization process is commonly explained by the two popular theories, namely the 'layer lattice theory' ([Burst, 1958a], [Burst, 1958b] and [Hower, 1961]) considering conversion of degraded illites through addition of Fe, and secondly, the 'verdissement of grains' involving progressive addition of K (from seawater) to the neoformed glauconitic smectites (Odin and Matter, 1981). According to our data, only authigenic alteration of $\mathrm{K}$-feldspar led to glauconitization in the Semri Group, and $\mathrm{K}_{2} \mathrm{O}$ contents of both glauconitic peloids and incipient phases are similar, therefore neither of these theories appears to fit. According to the second general hypothesis, higher $\mathrm{K}$ in the glauconitic minerals means a higher level of maturity; the estimated time range is $10^{3}-10^{4}$ years for neoformed or immature glauconites and about $10^{5}-10^{6}$ years for highly evolved glauconitic mica. Nevertheless, the observed compositional similarity between incipiently formed glauconitic minerals and well developed glauconitic peloids in our data rules out 'degree of maturity' as the main factor in dictating composition of the glauconitic minerals. More plausibly, high $\mathrm{a}_{\mathrm{K}}{ }^{+}$in the porewater arising from dissolution of $\mathrm{K}$ feldspars was conducive for the mineralization to proceed ([Dasgupta et al., 1990] and [Deb and Fukuoka, 1998]). The irregular boundaries of glauconitic mineral streaks along cleavages and fractures bear testimony to 'nibbling' or very localized alteration of the detrital feldspars. Extensive dissolution of K-feldspars leads to supersaturation of cations such as $\mathrm{Si}, \mathrm{Al}$ and $\mathrm{K}$ in porewater microenvironments and subsequent chemical reactions of the liberated ions with K-feldspar substrates possibly generated the ferric illites of varying composition. The high $\mathrm{Mg}$ content of the ferric illites is postulated to have been derived from the seawater as there is no other logical source for this ion in the host sandstones. It is suggested that the ferric illites of the Semri Group were possibly produced as pseudomorphs of K-feldspars in microenvironments with high $\mathrm{a}_{\mathrm{K}}{ }^{+}$, and that their Fe and $\mathrm{Mg}$ were derived from the seawater. Data points of the DFF and CSF form separate clusters, with slight overlap, in a scatter plot involving $\mathrm{Fe}_{2} \mathrm{O}_{3}$ (total) and $\mathrm{MgO}$ (Fig. 10E). This is attributable to either variation of seawater composition or longer reaction time in the case of CSF possibly because of a lower sedimentation rate. 


\section{Paleogeographic and stratigraphic implications of 'glauconitic minerals' from the semri group}

Ferric illites are generally reported from fluvial environments, but they are also found in lacustrine and lagoonal depositional settings. However, authigenic ferric illite, rich in $\mathrm{Mg}$, is reported rarely from marginal marine settings, but the source of $\mathrm{Mg}$ remains uncertain ([Berg-Madsen, 1983] and [Dasgupta et al., 1990]). The only reported occurrence from a deep marine environment, however, identified associated ferromagnesian minerals as the possible source of $\mathrm{Mg}$ (Deb and Fukuoka, 1998). In the case of both the Deoland Formation and the Chorhat Sandstone, Mg-rich ferric illite authigenesis has taken place on marine shelves, with increasing propensity for this alteration in a paleo-offshoreward direction. In our view, the only possible source for $\mathrm{Mg}$, in this case, was the seawater. It is thus postulated that ferric illite authigenesis in the entire marine realm is possible, but the mineral is more likely to be rich in $\mathrm{Mg}$ because much of it is available within the ambient seawater.

Glauconitization is one of the key characteristics of condensed zone sediments and can thereby be considered as typical of transgressive systems tracts ([Loutit et al., 1988], [Haq, 1991], [Amorosi, 1995], [Amorosi, 1997], [Amorosi and Centineo, 1997] and [Kitamura, 1998]). In the Deoland Formation it has, indeed, according to widely accepted palaeoenvironmental models, taken place within a TST, but in the Chorhat Sandstone Member it occurred within what is demonstrably the top part of a HST. This unexpected occurrence of authigenic glauconitic minerals in an essentially regressive depositional sequence is possibly related to the unique sedimentation style interpreted for many Precambrian epeiric seas ([Eriksson et al., 2001] and [Eriksson et al., 2005]). We suggest that the generally low rate of sedimentation in Proterozoic epeiric seas made authigenic ferric illite formation possible, even under HST conditions. Very low gradients allied to lower continental freeboard is considered typical for Precambrian epeiric sea floors (Eriksson et al., 2001). Sedimentation being largely controlled by episodic storms, as

appears to have been the case for the Semri Group deposits discussed here; its overall rate 
must have been very low on open shelves. On the basis of this latter contention, Sarkar et al. (2005) argued that HST deposits formed in Proterozoic epeiric seas are likely to be vertically stacked in the rock record, more often than not. Similar stacking was observed by Banerjee and Jeevankumar (2005) in the Koldaha Shale, another stratigraphic interval of the Semri Group (Fig. 2), central India. Frequent amalgamation of storm beds, even those apparently deposited near the storm wave base, within the Chorhat Sandstone HST clearly speaks for a very low overall sedimentation rate. Glauconitization in HST deposits may thus be normal against a Precambrian sedimentation background.

\section{Conclusions}

Glauconitic sandstones within the Semri Group are interesting for their Paleoproterozoic age and mineral chemistry of the glauconitic phases. Glauconitization in the Deoland Formation and the Chorhat Sandstone, central India took place exclusively on marine shelves, both during transgression and regression of the sea. Despite their marine origin, the 'glauconitic minerals' are of ferric illite composition, rich in Mg. High $\mathrm{a}_{\mathrm{K}}{ }^{+}$in pore water arising from extensive dissolution of detrital K-feldspar, and supply of $\mathrm{Fe}$ and $\mathrm{Mg}$ ions from seawater drove the glauconitization process, with increasing propensity for this alteration in the offshoreward direction. Structural formulae and chemical composition of the resultant mineral perfectly comply with that of 'glauconitic minerals'. Ferric illite can thus form in the marine realm, but is likely to be Mg-rich, and an outside source for $\mathrm{Mg}$ is not necessary. A low rate of sedimentation on Precambrian open shelves could have been conducive for authigenic development of ferric illite from K-feldspar-bearing sediments.

\section{References}

Amorosi, 1995 A. Amorosi, Glaucony and sequence stratigraphy: a conceptual framework of distribution in siliciclastic sequences, J. Sediment. Res. B65 (1995), pp. 419-425.

Amorosi, 1997 A. Amorosi, Detecting compositional, spatial, and temporal attributes of glaucony: a tool for provenance research, Sediment. Geol. 109 (1997), pp. 135-153. 
Amorosi and Centineo, 1997 A. Amorosi and M.C. Centineo, Glaucony from the Eocene of the Isle of Wight (southern UK): implications for basin analysis and sequencestratigraphic interpretation, J. Geol. Soc. London 154 (1997), pp. 887-896.

Auden, 1933 J.B. Auden, Vindhyan sedimentation in the Son valley, Mirzapur District, Mem. Geol. Surv. India 62 (1933), pp. 141-250.

Bailey, 1980 S.W. Bailey, Summary of recommendations of AIPEA nomenclature committee on clay minerals, Am. Miner. 65 (1980), pp. 1-7.

Baker, 1997 J.C. Baker, Green ferric clay in non-marine sandstones of the Rewan Group, southern Bowen Basin, Eastern Australia, Clay Miner. 32 (1997), pp. 499-506.

Banerjee, 1997 Banerjee, S., 1997. Facets of Mesoproterozoic Semri sedimentation, Son Valley, M.P. Unpublished Ph.D. Thesis. Jadavpur University, Kolkata, India.

Banerjee and Jeevankumar, 2005 S. Banerjee and S. Jeevankumar, Microbially originated wrinkle structures on sandstone and their stratigraphic context: Paleoproterozoic Koldaha Shale, central India, Sediment. Geol. 176 (2005), pp. 211-224.

Berg-Madsen, 1983 V. Berg-Madsen, High-alumina glaucony from the middle Cambrian of Orland and Bornholm, southern Baltoscandia, J. Sediment. Petrol. 53 (1983), pp. 875893.

Bose et al., 2001 P.K. Bose, S. Sarkar, S. Chakraborty and S. Banerjee, Overview of the Meso- to Neoproterozoic evolution of the Vindhyan basin, central India, Sediment. Geol. 141/142 (2001), pp. 395-419.

Bourgeois, $1980 \mathrm{~J}$. Bourgeois, A transgressive shelf sequence exhibiting hummocky cross stratification: Cape Sebastian Sandstone (Upper Cretaceous), Southwestern Oregon, J. Sediment. Petrol. 50 (1980), pp. 681-702. 
Brenchley and Newall, 1982 P.J. Brenchley and G. Newall, Storm-influenced inner shelf sand lobes in the Caradoc (Ordovician) of Shropshire, England, J. Sediment. Petrol. 52 (1982), pp. 1257-1269.

Burst, 1958a J.F. Burst, Glauconite pellets: their mineral nature and applications to stratigraphic interpretations, Bull. Am. Ass. Petrol. Geol. 42 (1958), pp. 310-327.

Burst, 1958b J.F. Burst, Mineral heterogeneity in glauconite pellets, Am. Miner. 43 (1958), pp. 481-497.

Catuneanu, 2002 O. Catuneanu, Sequence stratigraphy of clastic systems: concepts, merits, and pitfalls, J. Afr. Earth Sci. 35 (2002), pp. 1-43.

Dasgupta et al., 1990 S. Dasgupta, A.K. Chaudhuri and M. Fukuoka, Compositional characteristics of glauconitic alterations of K-feldspar from India and their implications, J. Sediment. Petrol. 60 (1990), pp. 277-281.

Deb and Fukuoka, 1998 S.P. Deb and M. Fukuoka, Fe-illites in a Proterozoic deep marine slope deposit of the Pranhita Godavari valley: their origin and environmental significance, J. Geol. 106 (1998), pp. 741-749.

Eriksson et al., 1998 P.G. Eriksson, K.C. Condie, H. Tirsgaard, W.U. Mueller, W. Altermann, A.D. Miall, L.B. Aspler, O. Catuneanu and J.R. Chiarenzelli, Precambrian clastic sedimentation systems, Sediment. Geol. 120 (1998), pp. 5-53.

Eriksson et al., 2001 P.G. Eriksson, M.A. Martins-Neto, D.R. Nelson, L.B. Aspler, J.R. Chiarenzelli, O. Catuneanu, S. Sarkar, W. Altermann and C.J.deW. Rautenbach, An introduction to Precambrian basins: their characteristics and genesis, Sediment. Geol. 141 (2001), pp. 1-35. 
Eriksson et al., 2005 P.G. Eriksson, O. Catuneanu, S. Sarkar and H. Tirsgaard, Patterns of sedimentation in the Precambrian, Sediment. Geol. 176 (2005), pp. 17-42.

Haq, 1991 B.U. Haq, Sequence stratigraphy, sea level change, and significance for the deep sea. In: D.I.M. Macdonald, Editor, Sedimentation, Tectonics and Eustasy: sea-level Changes at Active Margins vol. 12, Int. Ass. Sediment. Spec. Publ. (1991), pp. 3-39.

Hill et al., 2003 P.R. Hill, S. Meulé and H. Longuépée, Combined-flow processes and sedimentary structures on the shoreface of the wave-dominated Grande-riviére-de-laBaleine delta, J. Sediment. Res. 73 (2003), pp. 217-226.

Hower, $1961 \mathrm{~J}$. Hower, Some factors concerning the nature and origin of glauconite, Am. Miner. 46 (1961), pp. 313-334.

Hunter and Clifton, 1982 R.E. Hunter and H.E. Clifton, Cyclic deposits and hummocky cross-stratification of probable storm origin in Upper Cretaceous rocks of the Cape Sebastion area, southwestern Oregon, J. Sediment. Petrol. 52 (1982), pp. 127-143.

Ireland et al., 1983 B.J. Ireland, C.D. Curtis and J.A. Whiteman, Compositional variation within some glauconites and illites and implication for their stability and origins, Sedimentology 30 (1983), pp. 769-786.

Irwin, 1965 M.L. Irwin, General theory of epeiric clear water sedimentation, Bull. Am. Ass. Petrol. Geol. 49 (1965), pp. 445-459.

Jarrar et al., 2000 G. Jarrar, B. Amireh and D. Zachmann, The major, trace and rare earth element geochemistry of glauconites from early cretaceous Kurnub Group of Jordan, Geochem. J. 34 (2000), pp. 207-222. 
Jeevankumar, 2006 Jeevankumar, S., 2006. Facies sequence and biomat structures of the Semri Group in eastern Son valley. Unpublished Ph.D. Thesis. IIT Bombay, Mumbai, India.

Kitamura, 1998 A. Kitamura, Glaucony and carbonate grains as indicators of the condensed section: Omma Formation, Japan, Sediment. Geol. 122 (1998), pp. 151-163.

Kossovskaya and Drits, 1970 A.G. Kossovskaya and V.A. Drits, The variability of micaceous minerals in sedimentary rocks, Sedimentology 15 (1970), pp. 83-101.

Krassay, 1994 A.A. Krassay, Storm features of siliciclastic shelf sedimentation in the mid- Cretaceous epeiric seaway of northern Australia, Sediment. Geol. 89 (1994), pp. $241-264$.

Lee et al., 2002 C.H. Lee, S. Choi and M. Suh, High-iron glaucony from the continental shelf of the Yellow Sea off the southwestern Korean Peninsula, J. Asian Earth Sci. 20 (2002), pp. 507-515.

Loutit et al., 1988 T.S. Loutit, J. Hardenbol, P.R. Vail and G.R. Baum, Condensed sections: the key to age determination and correlation of continental margin sequences. In: C.K. Wilgus, B.S. Hastings, C. Kendali, H.W. Posamentier, C.A. Ross and J.C. Van Wagoner, Editors, Sea Level Changes: An Integrated Approach vol. 42, SEPM Spec. Publ., Tulsa, Oklahoma (1988), pp. 183-213.

Manghnani and Hower, 1964 M.H. Manghnani and J. Hower, Glauconites: cation exchange capacity of glauconite, Am. Miner. 49 (1964), pp. 545-572.

Moore and Reynolds, 1997 D.M. Moore and R.C. Reynolds Jr., X-Ray Diffraction and the Identification and Analysis of Clay Minerals (second ed.), Oxford University Press, Oxford, New York (1997) p. 378. 
Odin and Matter, 1981 G.S. Odin and A. Matter, De glauconiarum origine, Sedimentology 28 (1981), pp. 611-641.

Oschmann, 1990 W. Oschmann, Environmental cycles in the late Jurassic northwest European epeiric basin: interaction with atmospheric and hydrospheric circulations, Sediment. Geol. 69 (1990), pp. 313-332.

Pfluger and Seilacher, 1991 F. Pfluger and A. Seilacher, Flash flood conglomerates. In: G. Einsele, W. Ricken and A. Seilcaher, Editors, Cycles and Events in Stratigraphy, Springer-Verlag, Berlin, New York (1991), pp. 383-391.

Rasmussen et al., 2002 B. Rasmussen, P.K. Bose, S. Sarkar, S. Banerjee, I.R. Fletcher and N.J. Mc Naughton, 1.6 Ga U-Pb zircon ages for the Chorhat Sandstone, Lower Vindhyan, India: possible implication for early evolution of animals, Geology 30 (2002), pp. 103-106.

Ray, 2006 J.S. Ray, Age of the Vindhyan Supergroup: A review of recent findings, $J$. Earth Sys. Sci. 115 (2006), pp. 149-160.

Sarkar et al., 2005 S. Sarkar, S. Banerjee, P.G. Eriksson and O. Catuneanu, Microbial mat control on siliciclastic Precambrian sequence stratigraphic architecture: examples from India, Sediment. Geol. 176 (2005), pp. 195-209.

Sarkar et al., 2006 S. Sarkar, S. Banerjee, P. Samanta and S. Jeevankumar, Microbial mat-induced sedimentary structures and their implications: examples from Chorhat Sandstones, M.P., India, J. Earth Sys. Sci. 115 (2006), pp. 49-60.

Seilacher et al., 1982 A. Seilacher, Distinctive features of sandy tempestites. In: G. Einsele and A. Seilacher, Editors, Cyclic and Event Stratification, Springer-Verlag, Berlin (1982), pp. 333-349. 
Shaw, 1964 A.B. Shaw, Time in Stratigraphy, McGraw-Hill, New York (1964) p. 365. Swift and Rice, 1984 D.J.P. Swift and D.D. Rice, Sand bodies on muddy shelves: a model for sedimentation in the Western Interior Cretaceous Seaway, North America. In: R.W. Tillman and C.T. Siemers, Editors, Siliciclastic Shelf Sediments vol. 34, SEPM Spec. Publ., Tulsa, Oklahoma (1984), pp. 43-62.

Valeton et al., 1982 I. Valeton, A. Abdul-Razzak and D. Klussmann, Mineralogy and geochemistry of glauconite pellets from Cretaceous sediments in northwest Germany, Geol. Jb. D52 (1982), pp. 5-87.

Velde, 1985 B. Velde, Clay Minerals: Developments in Sedimentology vol. 40, Elsevier, Amsterdam (1985) p. 427.

Corresponding author. Tel.: +91 222576 7282; fax: +91 2225767253 . 